Hispania Sacra, Legalidad y conflictos, 58

117, enero-junio 2006, 171-222, ISSN: 0018-215-X

\title{
«LA OBEDIENCIA CONSTANTE Y LEAL A LA AUTORIDAD PÚBLICA». LEÓN XIII Y EL COMIENZO DE LA REGENCIA DE MARÍA CRISTINA*1
}

\author{
POR \\ ANDRÉS MARTÍNEZ EsTEBAN \\ Facultad de Teología «San Dámaso». Madrid
}

\section{RESUMEN}

Tras la muerte de Alfonso XII se abría un periodo de incertidumbre. El peligro de una nueva guerra civil y de levantamientos republicanos amenazaba la regencia de María Cristina. León XIII apoyó a la regente y pidió a obispos, clero y católicos españoles que aceptasen la legalidad.

PAlabRAS ClAVE: Alfonso XII, Regencia de María Cristina, León XIII, Obispos, Clero, Católicos españoles, Legalidad

\section{ABSTRACT}

After the death of Alfonso XII a period of uncertainty was opened. The danger of a new civil war and of republican raisings they were threatening Maria

* Siglas empleadas:

AMAE: Archivo Ministerio Asuntos Exteriores (España), Sección, legajo.

ASV NM: Archivo Secreto Vaticano, Nunciatura de Madrid, Título, Rúbrica, Sección, Número.

ASV SS: Archivo Secreto Vaticano, Secretaría de Estado, Rúbrica, Año, Fascículo.

DSS: Diario de Sesiones del Senado.

DSC: Diario de Sesiones del Congreso.

1 «La obediencia de los ciudadanos tiene como compañera inseparable una honrosa dignidad, porque no es esclavitud de hombre a hombre, sino sumisión a la voluntad de Dios, que ejerce su poder por medio de los hombres. Tan pronto como arraiga esta convicción en la sociedad, entienden los ciudadanos que son deberes de justicia el respeto a la majestad de los gobernantes, la obediencia constante y leal a la autoridad pública, el rechazo de toda sedición y la observancia religiosa de la constitución del Estado»: LeO PP. XIII, Epistola encyclica «Immortale Dei» de civitatum constitutione christiana: LEONIS XIII P. M., Acta, vol. V. Romae, 1886, p. 130; trad. española, Inmortale Dei, n. 8: J. L. GutiéRREZ García (ed.), Doctrina Pontificia, vol. II, Documentos políticos, Madrid, 1958, p. 200. 


\begin{abstract}
Cristina's regency. León XIII supported to Regent and asked to bishops, clergy and Spanish Catholics who were accepting the legality.
\end{abstract}

KEY WORDS: Alfonso XII, Maria Cristina's Regency, Leon XIII, Bishops, Clergy and Spanish Catholics,

La regencia de María Cristina recibió desde el comienzo el favor de la Santa Sede. Siguiendo la línea marcada por León XIII, los obispos optaron por la legalidad en la regencia y dieron la espalda a los carlistas. Estos, en cambio, eligieron el enfrentamiento. No sólo no aceptaron el poder constituido, sino que iniciaron una dura campaña periodística contra los obispos por connivencia con el liberalismo.

Las posturas están tomadas. La regencia se abrirá camino con la seguridad de un heredero a la Corona y con el apoyo de la Santa Sede y del Episcopado, ambos dispuestos a buscar la forma para que los españoles vivan en concordia y paz.

La política moderada de Sagasta favorecerá la consecución de la paz y la concordia en España.

\title{
1. LOS COMIENZOS DE LA REGENCIA
}

El proceso de pacificación y estabilidad que había traído la Restauración borbónica hacía presagiar que el futuro político de España, después de la frustrante experiencia del Sexenio revolucionario, sería de estabilidad. Sin embargo los acontecimientos iban a seguir otro curso y pondrían a prueba el sistema ideado por Cánovas.

La enfermedad del Monarca tendría un trágico final y dejaría al frente del gobierno a una Reina extranjera ${ }^{2}$, madre de dos hijas y esperando el nacimiento de un tercer hijo, sin saber si éste sería o no el futuro Príncipe de Asturias ${ }^{3}$. En estos momentos es cuando se demostraría que los años gastados en la estabilidad constitucional habían merecido la pena y la estructura monárquica soportó la posible catástrofe que parecía avecinarse como consecuencia de la muerte de Alfonso XII.

2 Pérez Galdós escribirá en 1912 de la Reina María Cristina: «Bien se le conoce el nacimiento, la estirpe, que es, como tú dices, la más encumbrada del mundo»: B. PÉREz Galdós, Cánovas. Episodios Nacionales 46. Serie final, p. 169.

3 «Contaba doña María Cristina treinta y siete años cuando recayeron en su erguida cabeza de mujer extraordinariamente distinguida y de firme carácter, las tocas de la viudez y el peso total de la corona que hasta entonces compartiera sin carga constitucional de ninguna especie ni vislumbres de poder. Joven, viuda, herido el corazón a fondo; en tierra extraña; amenazada por toda suerte de posibilidades adversas, sin hijo varón que asegurase la sucesión, de no ser niño el fruto de su embarazo ...»: M. FERNÁNDEZ Almagro, Historia política de la España contemporánea, vol. II, Madrid, 1959, pp. 1-2.

Hispania Sacra, Legalidad y conflictos, 58

117, enero-junio 2006, 171-222, ISSN: 0018-215-X 
Cánovas y Sagasta pondrán en juego toda su habilidad política para sostener la regencia. Además de un pacto político entre los dos partidos dinásticos, tendrán que conseguir el concurso de todas las fuerzas sociales, incluida la Iglesia, y conjurar el peligro de los antidinásticos.

\subsection{La muerte de Alfonso XII}

La muerte de Alfonso XII el 25 de noviembre de 1885 ponía en difícil situación política a la Monarquía española. El sistema creado en 1875 con la llegada del Rey y en 1876 con la aprobación de la nueva Constitución podía entrar en crisis. Ahora era necesario el acuerdo entre los partidos legales para sostener la regencia de María Cristina. Sin embargo, el gobierno temía la reacción del ejército y de la población. No hubo sorpresas de insurrecciones. Se mantuvo la tranquilidad, lo que permitió a Cánovas preparar un cambio de gabinete ${ }^{4}$. Presentó la dimisión y con él todo el gobierno. La regencia debía comenzar bajo el signo del partido liberal ${ }^{5}$.

La decisión de Cánovas estaba determinada, según él mismo dijo al nuncio Rampolla ${ }^{6}$, por el cansancio que la situación política le había provocado. La Reina sería Regente hasta la mayoría de edad de la Princesa de Asturias, María de las Mercedes, al menos mientras no se supiera el desenlace del embarazo de la Reina. No pensaba lo mismo Rampolla, creía más conveniente la continuidad del ministerio Cánovas, lo que evitaría cambios en la política del país. Sin embargo, si se confirmaba la llegada al poder de Sagasta, éste había dado garantías suficientes para esperar que el nuevo gobierno mantuviera una buena relación con la Iglesia. Ésta no tenía nada que temer.

A pesar de las buenas intenciones, existía cierta inestabilidad en la política española. Faltaba cohesión entre los partidos; los ataques eran mutuos, buscando siempre el propio interés y el deseo de alcanzar el poder. Había que añadir cierta tensión que se vivía en el seno de la familia real. Algunos todavía veían en la Reina Isabel II una posible solución a la crisis, teniendo en

4420 Rampolla-Jacobini, 25 noviembre 1885. ASV NM 533, Tít. V, Rub. I, Sez. III 1A, ff. 463-464.

5 Cifra. Rampolla-Jacobini, 25 noviembre 1885. ASV NM 534, Tít. V, Rub. II, Sez. III 19, f. 539.

6 Mariano Rampolla del Tindaro (1843-1913). Alumno del Colegio Capránica, ingresó en la Academia de Nobles Eclesiásticos en 1867. En 1875 es destinado a la nunciatura de Madrid como auditor de la misma. Regresa a Roma en 1877, donde desempeña el cargo de Secretario de la Congregación de Asuntos Eclesiásticos Extraordinarios. León XIII lo nombra nuncio en España en 1882 y el 14 de marzo de 1887 lo nombra cardenal y el 1 de junio, después de la muerte del cardenal Jacobini, el Papa lo nombra Secretario de Estado. Cfr. R. RITZLER-P. SEFRIN, Hierarchia Catholica Medii et Recenctioris Aevi, vol. VIII. Patavii, 1979, p. 33. Sobre la labor del nuncio Rampolla en Madrid: Cfr. C. RoBLES MuÑoz, Insurrección o legalidad. Los católicos y la Restauración, Madrid, 1988, pp. 382-398. 
cuenta que la Reina María Cristina era una extranjera sin experiencia en la política.

Tal estado de cosas podía llevar a los antidinásticos a intentar un nuevo asalto al poder. Había que evitar que el pretendiente carlista intentara una sublevación que diera lugar a una nueva guerra civil. Una solución que se quiso dar fue el matrimonio entre la Princesa de Asturias y el hijo mayor de D. Carlos ${ }^{7}$. No sería posible. La reconciliación entre las dos familias borbónicas debía ir más allá del simple hecho de evitar nuevas guerras. España había entrado en el camino del progreso y de la libertad. El regreso de los carlistas sería el retorno al absolutismo monárquico y a la intolerancia religiosa ${ }^{8}$.

El mismo día de la muerte del Rey, Cánovas presentó la dimisión del gobierno. Esa misma mañana habían hablado Martínez Campos y Cánovas de las posibles salidas a la crisis. Por la tarde, Cánovas fue a El Pardo para tratar con la Regente y presentar la dimisión de todo el gabinete, pidiendo que llamara a Sagasta a formar nuevo gobierno? .

La actitud de los liberales no se hizo esperar. El general López Domínguez afirmó que cumpliría con sus deberes siguiendo los medios legales para salvar el orden, la libertad y la Monarquía ${ }^{10}$. Sagasta, por su parte, comenzó a formar su ministerio, tomando las medidas oportunas para garantizar el orden, pero sin ser excepcionales ya que había que dar sensación de normalidad ${ }^{11}$. El 27 de noviembre Rampolla comunicaba al Secretario de Estado la lista de los nuevos ministros ${ }^{12}$.

El Siglo Futuro atacó la alianza entre los dinásticos. Ponía de relieve cómo ambos políticos, Sagasta y Cánovas, presentaban el mismo modelo de política. Ambos liberales, por tanto, sólo quieren asegurar las libertades de perdición con el sostenimiento de la Monarquía ${ }^{13}$. No podía ser de otra forma. La regencia debía encontrar el apoyo firme de los distintos partidos, para ello tenían que estrechar la unión y concordia entre las fuerzas políticas y entre los grupos que se integraban en estos. Ésta sería la garantía del progreso y de la paz del país. Era el momento de demostrar si España era un pueblo que sabía gobernarse o

7421 Rampolla-Jacobini. Minuta, 26 noviembre 1885. ASV NM 534, Tít. V, Rub. II, Sez. III 19, ff. 548-549.

8 «A nuestro Padre Santo León XIII», El Liberal (6 diciembre 1885), 1.

9 «Cánovas presentó la dimisión a la Reina», El Imparcial (26 noviembre 1885), 2-3. El Real Decreto con el nombramiento del nuevo Presidente: DSS, 1 (27 noviembre 1885), 5.

10 «Actitud de la izquierda», El Imparcial (26 noviembre 1885), 2-3.

11 «o que piensa Sagasta», El Imparcial (26 noviembre 1885), 2-3.

12 Cifra. Rampolla-Jacobini, 27 noviembre 1885. ASV NM 534, Tít. V, Rub. II, Sez. III 19, f. 540. Al día siguiente era Moret quien anunciaba a Rampolla la formación del nuevo Gabinete: Moret-Rampolla, 28 noviembre 1885. ASV NM 534, Tít. V, Rub. II, Sez. III 19, ff. 541-542.

13 «Suras del Corán mestizo», El Siglo Futuro (27 noviembre 1885), 1. 
un pueblo dividido ${ }^{14}$. La política de la regencia no podía ser distinta de la que se había iniciado con la Constitución de 1876.

«Es continuación del Reinado de Alfonso XII política reparadora de las llagas de la patria, política de paz, de unión, de concordia, donde quepan todos los españoles, todos los intereses y todas las esperanzas; donde dentro de la unidad de la Monarquía en su actual forma jurídica, se concilien todos los criterios y todas las tendencias y todas sirvan para asegurar igualmente la libertad y el orden...» ${ }^{15}$.

La Regente tenía un papel difícil ${ }^{16}$. Dos eran los intereses que debía conciliar. Por una parte estaban las divisiones en la misma familia real. Isabel II creía tener posibilidades de regresar al trono ${ }^{17}$. Rampolla se entrevistó con ella. Indicó la obligación de dar apoyo firme a la Reina y la necesidad de mantener unida a la familia real ${ }^{18}$. La clase alta madrileña estaba haciendo el vacío a la Regente y visitaba con frecuencia a la Reina madre. En opinión de algunos políticos la regencia no tenía una base sólida y se lamentaban que Isabel II hubiera sido dejada de lado en los derechos sucesorios. Al final Martínez Campos pidió a Isabel II que abandonara la Corte para dejar libertad a la Regente ${ }^{19}$.

Otro de los problemas que debía solucionar la regencia de María Cristina era la unidad entre los partidos políticos. Ésta se había conseguido por el acuerdo entre Cánovas y Sagasta. Sin embargo la decisión del jefe de los conservadores acarreó la división en su propio partido. Fue Romero Robledo quien rompió la disciplina de partido y se apartó de la decisión tomada por Cánovas. Tal disidencia no cambiaría el acuerdo entre partidos. El conservador mantendría la

14 «... el pueblo español es un pueblo digno [...] que en los momentos de peligro, sabe sobreponerse»: B. PÉrez Galdós, Fortunata y Jacinta, vol. I, Madrid, 2000, p. 277. La novela fue escrita en 1887. Un comentario similar hizo Le Temps a propósito de la muerte de Alfonso XII. Artículo que reprodujo El Liberal (30 noviembre 1885), 1.

15 «La política de la Regencia», La Época (11 febrero 1886), 1.

${ }^{16} \mathrm{La}$ madre de la Reina M. ${ }^{\text {a }}$ Cristina escribió a Rampolla exponiéndole la situación difícil en la que se encontraba su hija, especialmente con los cambios políticos y sociales que se estaban viviendo en toda Europa. Archiduquesa Isabel-Rampolla, 4 diciembre 1885. ASV NM 533, Tít. V, Rub. I, Sez. III 1C, ff. 761-762.

${ }^{17}$ La Reina madre, poco antes de la muerte del Rey, se encontró con Martínez Campos, como relata León y Castillo: «[...] doña Isabel, dirigiéndose a Martínez Campos, le preguntó sin rodeos:

- ¿Qué va a ocurrir aquí si sobreviene una desgracia?

No vaciló el general en la contestación:

- Señora: la legalidad en la Regencia de doña María Cristina.

En el rostro de la Reina dibujóse un gesto extraño, mezcla de sorpresa y desencanto, como si allá en su interior hubiese sentido de pronto derrumbarse ilusiones que le hiciesen concebir algunos cortesanos, más devotos de su persona que avisados»: Vid. M. FernándeZ AlmAGro, Historia política de la España contemporánea, vol. I, p. 458.

18431 Rampolla-Jacobini. Minuta 18 diciembre 1885. ASV NM 533, Tít. V, Rub. I, Sez. III 1A, ff. 498-499.

19 «Qué pasa en Palacio?», El Liberal (28 diciembre 1885), 1. 
unidad y una jefatura indiscutible ${ }^{20}$ Entre los liberales, en cambio, las luchas estarían por alcanzar un puesto en el nuevo gobierno, lo que podría adelantar el regreso de los conservadores al poder. Sin embargo, la concordia que se había logrado entre los dos partidos hacía presagiar que, si permanecía el pacto entre Cánovas y Sagasta, la Monarquía estaba asegurada ${ }^{21}$. Y esto se demostró el día del juramento de la Regente.

El 30 de diciembre la Reina juraba la Constitución ante el Congreso y el Senado $^{22}$. Fue la ocasión para poner de manifiesto la tranquilidad que reinaba en la población y en el ejército, y la unidad entre los dos principales partidos monárquicos. Fue un elemento importante que evitó cualquier intento de sublevación por parte de los antidinásticos, que no esperaban tal acuerdo.

\subsection{La intervención de Rampolla y la declaración del episcopado}

Había que dar un paso más. La unidad en torno a la Regente exigía la incorporación del episcopado a la política de pacificación. Era la forma de dar una base sólida a la regencia y fortalecer la Monarquía. Con este fin, Manuel Alonso Martínez, ministro de Justicia, mandó una circular a los obispos invitándoles al funeral del Rey. Con este acto pondrían de manifiesto su adhesión a la Coro$\mathrm{na}^{23}$. El mismo día escribió a Rampolla para que intercediera ante los obispos. Quería que acudieran a Madrid el mayor número posible de ellos. Los obispos recelaban de la política que llevarían adelante los liberales, hecho que podía ir en perjuicio de la propia Monarquía ${ }^{24}$.

Rampolla dirigió una circular a aquellos obispos que pensó podrían asistir a las exequias. En ella informaba de la petición hecha por Alonso Martínez y de forma confidencial añadía que el mismo Papa había nombrado al nuncio como su representante oficial en los actos que se celebrarían por la muerte del Rey. Era la forma de indicar cuál era la postura de León XIII ante el nuevo gobierno ${ }^{25}$.

20 «Movimiento de reorganización», La Época (3 enero 1886), 1. Más adelante Romero Robledo se unirá a López Domínguez. «La reunión de los coalicionistas», La Época (12 marzo 1886), 1.

21435 Rampolla-Jacobini, 31 diciembre 1885. ASV SS 249 (1886), 2, ff. 81-86.

Entre Sagasta y Cánovas hubo un pacto que en la época se denominaba «otorgar la beligerancia», por el que se reconocía el derecho del adversario político a ostentar el poder de acuerdo a unas normas básicas. De esta forma se ponía en marcha el turno pacífico. Cfr. A. LARIO, El Rey, piloto sin brújula. La Corona y el sistema político de la Restauración (1875-1902), pp. 69-79.

22 DSS, 3 (30 diciembre 1885), 20.

${ }^{23}$ Circular. Alonso Martínez-Obispos, 3 diciembre 1885. ASV NM 533, Tít. V, Rub. I, Sez. III 1C, f. 612 .

24 Alonso Martínez-Rampolla, 3 diciembre 1885. ASV NM 533, Tít. V, Rub. I, Sez. III 1C, f. 608.

25 «El Sr. ministro de Gracia y Justicia al darme copia de la invitación que en día de ayer ha circulado a los Prelados de España para que si les es posible, asistan a las exequias de S. M. el Rey Don Alfonso XII me ha rogado les manifieste yo también la esperanza que tiene el gobierno de que el episco-

Hispania Sacra, Legalidad y conflictos, 58

117, enero-junio 2006, 171-222, ISSN: 0018-215-X 
La respuesta de los obispos fue unánime, con algunas excepciones. Se dispensaron los arzobispos de Compostela, Tarragona y Burgos. Los tres por motivos de salud ${ }^{26}$.

El funeral se celebró la mañana del 12 de diciembre. Lo presidió el obispo de Madrid, con la asistencia de los tres cardenales españoles y veinticinco obispos. El arzobispo de Valladolid se encargó de la oración fúnebre que publicó la Gaceta de Madrid ${ }^{27}$.

La reunión de los obispos en Madrid sirvió para dar un paso adelante en las relaciones entre la Iglesia y el Estado. La presencia de tantos obispos causó una impresión favorable en el gobierno. Así lo pusieron de manifiesto Alonso Martínez, Sagasta y Segismundo Moret al nuncio. Por su parte, Rampolla consiguió reunir a los obispos en la nunciatura con el fin de ponerse de acuerdo en una misma dirección. Era la ocasión propicia para que, siguiendo las enseñanzas pontificias, tuvieran una actitud uniforme con la prensa católica que estaba alimentando las divisiones entre los católicos ${ }^{28}$.

Los obispos enviaron un telegrama a León XIII donde manifestaban su adhesión a la encíclica Immortale Dei y a la carta del Papa al arzobispo de París sobre el conflicto con el cardenal Pitra ${ }^{29}$. Al mismo tiempo escribían una pastoral a los fieles de sus diócesis. El documento tuvo una gran importancia, ya que puso de manifiesto cuál era su postura ante la regencia y cuál debía ser la posición de los católicos. Era una defensa de las libertades individuales, salvados los principios católicos: libertad de discutir y sostener posturas diversas sobre las formas de gobierno. Esto significaba que nadie, en especial periódicos o revistas, podían apropiarse de la idea católica, como si su postura fuera la única

pado español concurra a dichos funerales. Haciéndome intérprete de los sentimientos de mis Hermanos, he creído poder asegurar al Sr. ministro que no dejarán de dar mayor esplendor a la solemnidad religiosa con su asistencia los Prelados, a quienes especiales atenciones de su cargo, el estado de su salud, la distancia o la dificultad de las comunicaciones no les impida emprender un viaje a la Corte; pero ahora me cabe la satisfacción de añadir a V. confidencialmente que Nuestro Ssmo Padre ha querido Él mismo tener una especial representación en los funerales del Rey, confiándome al efecto el honroso encargo de asistir en su nombre y representación»: Rampolla-Obispos de (Compostela, Calahorra, Granada, Cádiz, Burgos, Barcelona, Valencia, Cuenca, Lérida, Salamanca, Zamora, Sigüenza, Córdoba, Vitoria, Murcia, Segovia, Málaga, Orihuela, Jaén, Ávila, Tarragona, Gerona, Santander, Lugo, Teruel, Ciudad-Rodrigo, Almería) [sic], 4 diciembre 1885. ASV NM 533, Tít. V, Rub. I, Sez. III 1C, f. 614.

${ }^{26}$ Payá y Rico-Rampolla, 6 diciembre 1885. ASV NM 533, Tít. V, Rub. I, Sez. III 1C, ff. 620r621v.; Vilamitjana y Vila-Rampolla, 7 diciembre 1885. Ibid., f. 622; Fernández de Castro-Rampolla, 11 diciembre 1885 . Ibid., f. 650.

27429 Rampolla-Jacobini, Madrid 12 diciembre 1885. ASV NM 533, Tít. V, Rub. I, Sez. III 1A, ff. 467-468. Gaceta de Madrid, año CCXXIV, n. ${ }^{\circ}$ 348, 14 diciembre 1885, Tomo IV, pp. 861-863.

28430 Rampolla-Jacobini, 17 diciembre 1885. ASV SS 249 (1886), 2, ff. 53-56.

29 Obispos-León XIII, 12 diciembre 1885. ASV SS 249 (1886), 2, ff. 57-58. Sobre este conflicto con el cardenal Pitra: Cfr. C. RoBles MuÑz, Insurrección o legalidad. Los católicos y la Restauración, pp. 357-379. 
dentro de la Iglesia. La prensa católica debía someterse a la autoridad episcopal, la única que podía discernir sobre la catolicidad de determinadas doctrinas. Era, por tanto, lícito debatir con los adversarios políticos cuestiones de derecho público no definidas por el Papa y los obispos ${ }^{30}$.

El mensaje publicado en la prensa fue comentado favorablemente y dio un gran prestigio a la Santa Sede. Los obispos acordaron prestar todo su apoyo al gobierno y no crear dificultades. Para ello se alejarían de las cuestiones políticas, siempre y cuando no afectasen a los intereses de la Iglesia ${ }^{31}$. También acordaron publicar el mensaje al Papa en los boletines diocesanos. Incluso aquellos obispos que no acudieron al funeral del rey se adhirieron al mensaje y a la carta pastoral $^{32}$. Fue un acto unánime de todo el episcopado español. Pero quien había conseguido la concordia entre los obispos era Rampolla. El nuncio quiso permanecer en segundo plano y no hacer pública su actuación, como algunos obispos pedían. El mensaje al Papa debía aparecer como un acto que partió de la iniciativa de los propios obispos y no de la Santa Sede. El efecto que esto produciría serviría para reconciliar a la Iglesia con las instituciones y la opinión pública. No sólo la Reina y el gobierno, sino todos los hombres honestos sabrían apreciar el significado que tal hecho tenía ${ }^{33}$.

No le faltó razón a Rampolla. Moret leyó el mensaje en el Consejo de ministros, con la aprobación de todo el gabinete, y pidió un ejemplar para entregárselo a la Reina. Era un hecho de gran trascendencia para la pacificación y tranquilidad del país, y desbarataba los planes de los partidos antidinásticos. El gobierno decidió dar comunicación del mismo a sus representantes diplomáticos. «Se considera[ba] un gran paso que la Iglesia se sitúe en un plano superior a miras propiamente humanas y alejada de las pasiones políticas» ${ }^{34}$.

\footnotetext{
30 «Mensaje de los obispos a sus fieles con motivo del funeral de Alfonso XII, 14 diciembre 1885. Han enviado un mensaje a León XIII en el que manifiestan el acatamiento a sus enseñanzas. Declaran: 1. La religión y la política son cosas muy distintas y no deben confundirse. Salvada la unidad de fe y los principios católicos, pueden sostenerse controversias sobre la mejor clase de gobierno. 2. Ningún periódico o revista puede declarar si una determinada opinión o teoría política es o no católica. Esto corresponde a los obispos. 3. Dejando a un lado las controversias política, cualquier periódico o revista que se declare católico debe estar sometido a la autoridad episcopal. 4. Es lícito a los escritores católicos defender y propagar sus doctrinas, y combatir lealmente a sus adversarios, sin faltar a la caridad y sin exigir que sus escritos tengan más valor doctrinal que otros. 5. Los obispos publicaran en sus Boletines estas disposiciones»: «Documento que los Prelados reunidos en Madrid con motivo de las honras fúnebres que allí se han celebrado pro el alma del malogrado Rey D. Alfonso XII (Q. S. G. H.) dirigen a los fieles de su Diócesis», La Cruz, 1 (1886), 94.

31430 Rampolla-Jacobini, 17 diciembre 1885. ASV SS 249 (1886), 2, ff. 53-56.

32 Algunos obispos comenzaron a mandar en seguida mensajes de adhesión y publicaron la carta en los boletines diocesanos. Así hicieron los obispos de Menorca, Palencia y Lugo entre otros. 446 Rampolla-Jacobini. Minuta, 16 enero 1886. ASV NM 533, Tít. V, Rub. I, Sez. III 1C, f. 594.

33436 Rampolla-Jacobini. Minuta, 4 enero 1886. ASV NM 533, Tít. V, Rub. I, Sez. III 1C, f. 588.

34440 Rampolla-Jacobini. Minuta, 9 enero 1886. ASV NM 533, Tít. V, Rub. I, Sez. III 1C, ff. 592-593.
}

Hispania Sacra, Legalidad y conflictos, 58

117, enero-junio 2006, 171-222, ISSN: 0018-215-X 
En una audiencia particular la Reina comunicó a Rampolla que deseaba concederle la Gran Cruz de Carlos III. El gobierno estaba agradecido por la mediación de la Santa Sede y la actuación del nuncio durante la muerte del rey. Manifestó sus simpatías por Sagasta. El gobierno había conseguido pacificar el país ante posibles intentos de sublevación. Rampolla habló de la preocupación de la Santa Sede ante las posibles reformas en la enseñanza y las innovaciones que Eugenio Montero Ríos, ministro de Instrucción Pública, podía introducir. La Reina dio garantías al nuncio. No había nada que temer ${ }^{35}$.

La prensa se hizo eco del mensaje de los obispos. La asistencia de los obispos al funeral del rey y el documento episcopal eran la muerte del carlismo ${ }^{36}$. Se quitaba, de esta forma, cualquier argumento a aquellos que pretendían identificar la postura carlista con la católica ${ }^{37}$. La prensa antiliberal, por su parte, guardó silencio. No publicaron el mensaje o lo publicaron sin la parte dispositi$\mathrm{va}^{38}$. La Época denunció la maniobra carlista. Los periódicos y el partido carlista pretendían apropiarse el derecho a ser los únicos y verdaderos católicos. Utilizaban la religión para sus fines políticos. La Fe, periódico portavoz del carlismo, pretendió apoderarse de las enseñanzas del Papa y de los obispos; el partido tradicionalista se declaraba como el único partido católico. Sin embargo, el Papa y los obispos reconocían la monarquía legítima de Alfonso XII. La Época, que reprodujo el artículo de La Fe, respondió diciendo que la Iglesia había dejado de ser patrimonio del partido carlista, y había separado la causa católica de la causa política ${ }^{39}$.

\section{LOS PARTIDOS ANTIDINÁSTICOS}

La unión de los partidos dinásticos debía conjurar el peligro de los partidos que estaban al margen de las instituciones, carlistas y republicanos. Unos y otros pondrían todos los medios para desestabilizar el Régimen constitucional, pero la falta de respuesta por parte de la población civil demostraría que los españoles estaban cansados de guerras y deseaban la paz.

El primer ataque vendría por parte de la prensa tradicionalista. No gustó al sector más integrista del carlismo la postura de los obispos ante la Regencia y atacaron al episcopado.

35445 Rampolla-Jacobini. Minuta, 14 enero 1886. ASV NM 533, Tít. V, Rub. I, Sez. III 1C, ff. 753-755.

36 «La voz de los Prelados», La Época (8 enero 1886), 1.

37 «Documento importantísimo», El Imparcial (8 enero 1886), 1.

38 La Cruz al publicar el mensaje de los obispos hizo esta indicación. Vid. La Cruz, 1 (1886), 94, nota 1 .

$39 « \mathrm{O}$ lo uno o lo otro», La Época (10 enero 1886), 1.

Hispania Sacra, Legalidad y conflictos, 58 117, enero-junio 2006, 171-222, ISSN: 0018-215-X 


\subsection{La ofensiva integrista}

La reacción de la prensa carlista y antiliberal puso de manifiesto su posición ante la Regencia. Era inamovible. Consideraban que se les pedía renegar de sus principios para sostener al gobierno Sagasta y no estaban dispuestos. No renunciaban a la unidad católica frente a una Constitución liberal, y a la enseñanza de la Iglesia católica, como fundamento de toda sociedad cristiana ${ }^{40}$. Su norma de conducta seguiría siendo la misma, combatir las libertades de perdición. No podían afirmar que eran católicos en lo privado y manifestarse contrarios a la enseñanza de la Iglesia en lo público. Esto significaría seguir la doctrina liberal ${ }^{41}$.

Defendían como bandera política la Immortale Dei. Al contrario de lo que afirmaba La Unión Católica, en la encíclica de León XIII no se podía justificar uno solo de los artículos de la Constitución de 1876. Todo lo contrario, condenaba las libertades modernas sancionadas en esa Constitución ${ }^{42}$.

Consideraban su postura como la única viable y posible para los católicos. El partido tradicionalista aspiraba a restaurar en España todas las enseñanzas sociales de la Iglesia. Por eso, sólo podía ser considerado partido católico aquel que defendiese y tuviera como credo político la Immortale Dei ${ }^{43}$. La situación que vivía el país les pedía transigir con el liberalismo. Reafirmaron el non possumus. El derecho nuevo propugnado por las ideas liberales descartaba los principios fundamentales de toda sociedad cristiana. Igualmente el derecho cristiano, la sumisión de los pueblos y príncipes a Dios y la subordinación del Estado a la Iglesia. Todo esto estaba fuera de cualquier transacción. León XIII lo había dicho claramente. Un gobierno debía ser cristiano en el fondo y no condescender con el derecho nuevo y las libertades modernas. Con los partidos liberales no se podía transigir ${ }^{44}$.

\subsubsection{Los ataques contra los obispos}

La polémica se extendió por toda España. La prensa católica regional seguía las directrices marcadas por El Siglo Futuro desde Madrid. Reaccionó en contra de los obispos por su adhesión y apoyo a la Monarquía. En Salamanca, Tomás Cámara ${ }^{45}$, obispo de la diócesis, denunció la actuación del periódico integrista

40 «Nuestro credo político», El Siglo Futuro (16 diciembre 1885), 1.

41 «Nuestra norma de conducta», El Siglo Futuro (17 diciembre 1885), 1-2.

42 «La tesis cristiana de La Unión», El Siglo Futuro (18 diciembre 1885), 1.

43 «Para rectificar y ratificar», El Siglo Futuro (18 diciembre 1885), 1.

44 «¿En qué se puede transigir?», El Siglo Futuro (23 diciembre 1885), 1.

45 Tomás Cámara y Castro (1847-1904), estudió en el Seminario de Burgos y a los dieciséis años profesó en el colegio de los agustinos. Fue el fundador de la Revista Agustiniana, que más tarde se llamaría La Ciudad de Dios. Consagrado obispo el 28 de octubre de 1883, fue primero auxiliar de Toledo

Hispania Sacra, Legalidad y conflictos, 58

117, enero-junio 2006, 171-222, ISSN: 0018-215-X 
La Tesis, su director apoyaba la política de Ramón Nocedal y pedía a éste la ruptura con los obispos. En varios artículos publicados, el periódico había cambiado el sentido de las homilías que el obispo pronunciaba en la catedral ${ }^{46}$. Según La Tesis, el obispo al comentar la Immortale Dei en una de ellas, había pretendido rectificar las palabras de Pío IX sobre los católicos liberales. El obispo denunció también la postura de algunos católicos que acudían a los obispos más afines con sus ideas políticas ${ }^{47}$

Respondió Rampolla a la denuncia de Cámara ${ }^{48}$. La actuación de los obispos debía ser firme y prudente. Tenían que exigir la obediencia a la jerarquía, pero al mismo tiempo tenían que mostrar su imparcialidad en las discusiones políticas, no inclinándose ni a favor ni en contra de ningún partido político. Cámara publicó en el Boletín de la diócesis una nota en la que afirmaba que la información dada por La Tesis sobre su homilía era falsa ${ }^{49}$. El periódico publicó la nota del obispo pero mantuvo su postura. Habían consultado a «personas peritas y de escrupulosa conciencia» sobre las palabras pronunciadas por Cámara, confirmando que lo denunciado por La Tesis era verdad ${ }^{50}$.

Poco tiempo después La Tesis suspendía su publicación. Sin embargo aparecía un nuevo periódico carlista, La Tradición ${ }^{51}$. La Tesis, acusada por el obispo de heterodoxa, pretendía la defensa de la Iglesia frente al derecho nuevo. Ahora, el nuevo periódico sostendría el antiguo derecho español católico y monárquico. Defendería, en el terreno político, la verdad íntegra bajo la bandera carlista contra el liberalismo. En consecuencia afirmaba el más absoluto antiliberalismo $^{52}$. El nuevo periódico comenzó publicando unas cartas del sacerdote sevillano Francisco Mateos $\mathrm{Gago}^{53}$, caracterizado integrista. Rampolla llamó la atención al Vicario capitular de Sevilla, tras recibir la denuncia del

y después, Tít.ular de la diócesis de Salamanca. Cfr. A. VÁZQuEZ GARCíA, «El Padre Cámara figura preclara del episcopado español y fundador de los estudios eclesiásticos superiores de Calatrava», Hispania Sacra, 7 (1954), 327-340.

En torno a la polémica del obispo de Salamanca con los integristas: Cfr. M. A. OrCASITAS, «Tensiones del obispo Tomás Cámara con el integrismo salmantino», La Ciudad de Dios, 271 (2004), 10151065 .

46 Cámara-Rampolla, 21 enero 1886. ASV NM 537, Tít. VI, Rub. I, Sez. V 16, ff. 723-726.

47 «Carta del señor Don Francisco Mateos Gago», El Siglo Futuro (15 enero 1886), 1-2.

48 Rampolla-Cámara. Minuta, 27 enero 1886. ASV NM 537, Tít. VI, Rub. I, Sez. V 16, f. 730.

49 El Siglo Futuro (18 enero 1886), 1.

50 El Siglo Futuro (21 enero 1886), 1.

51 Cámara-Rampolla, 17 marzo 1886. ASV NM 537, Tít. VI, Rub. I, Sez. V 16, ff. 740-741.

52 «Una baja y dos altas», El Siglo Futuro (1 marzo 1886), 1.

53 Francisco Mateos Gago (1827-1890), sacerdote, pedagogo, arqueólogo y periodista. Doctor en teología por la Universidad de Granada, fue catedrático de teología en la Universidad de Sevilla. Nombrado por Pío IX teólogo del Concilio Vaticano I, rehusó tal nombramiento. Cfr. «Mateos Gago (Francisco)», en Enciclopedia Universal Ilustrada Europeo-Americana (Espasa), vol. 33, Bilbao-MadridBarcelona, 1929, p. 908. 
obispo de Salamanca. Había que seguir insistiendo en la obediencia que los católicos debían a sus obispos. En esto no se podía vacilar ${ }^{54}$.

Los artículos de La Tesis eran sólo una parte de la ofensiva integrista contra los obispos. Un ataque que se extendía al nuncio, como se puso de manifiesto con la publicación de un artículo de La Ilustración popular y económica de Valencia, también de color carlista.

José María Settier, director de la revista, arremetía contra Rampolla y la Santa Sede. Ponía en cuestión la autoridad vaticana en sus recomendaciones sobre la relación de los católicos con los poderes constituidos. La Santa Sede y el nuncio tenían una misión diplomática, en consecuencia no podían manifestar de manera clara y abierta su postura, ni podían ser contundentes en refutar los principios liberales de los gobernantes. La revista denunciaba de esta forma, la inspiración masona y liberal del gobierno español. Eso obligaba a poner en duda la validez de las personas presentadas como candidatos al episcopado $^{55}$.

Rampolla llamó la atención de Antolín Monescillo ${ }^{56}$, arzobispo de Valencia, sobre el artículo, como ya había hecho en otras ocasiones ${ }^{57}$. La revista publicaba los artículos que enviaban desde Madrid y se copiaban los publicados en otros periódicos católicos. La prensa llamada católica, con el apoyo del clero, estaba desvirtuando el sentido de las enseñanzas pontificias ${ }^{58}$. Detrás de la revista estaba, según Monescillo, el propio Nocedal. La revista pasaba por un momento de baja en las suscripciones y la sostenían antiguos miembros de la junta de la Cofradía de los Desamparados. Quería conseguir la retractación del director, pero había preparado ya la condena de la revista. No consiguió que Settier diera marcha atrás y condenó la revista ${ }^{59}$.

\footnotetext{
${ }^{54}$ Rampolla-Cámara. Minuta, 18 marzo 1886. ASV NM 537, Tít. VI, Rub. I, Sez. V 16, ff. 742743.

55 «Un peligro para la Iglesia católica», La Ilustración popular económica de Valencia. Revista católica de Ciencias, Artes e Industria, Año XVI, 10 de febrero de 1886, n. ${ }^{\circ}$ 594, pp. 72-75.

56 Antolín Monescillo y Viso (1811-1897). Estudió filosofía y teología en Toledo, donde obtuvo en 1839 la cátedra de teología pastoral. En junio de 1861 es preconizado para la diócesis de Calahorra y La Calzada. Cuatro años más tarde es trasladado a Jaén. Participó en el Concilio Vaticano I como miembro de la Diputación de la Fe. En 1877 pasó a la diócesis de Valencia y en 1884 era nombrado cardenal. Durante la regencia de María Cristina, en 1892, sería preconizado para la Diócesis primada de Toledo. Cfr. J. MarTín TeJEdor, «Monescillo y Viso, Antolín», en DHEE, vol. III, pp. 1721-1723.

Sobre los conflictos entre Monescillo y la prensa integrista: Cfr. R. M. ${ }^{\text {a }}$ SANZ DE DIEGO, Medio siglo de relaciones Iglesia-Estado: El Cardenal Antolín Monescillo y Viso (1811-1897), Madrid, 1979, pp. 289-292.

57 Rampolla-Monescillo. Minuta, 23 febrero 1886. ASV NM 537, Tít. VI, Rub. I, Sez. V 17, f. 798 .

58 Monescillo-Rampolla, 25 febrero 1886. ASV NM 537, Tít. VI, Rub. I, Sez. V 17, ff. 800-801.

59 Monescillo-Rampolla, 27 febrero 1886. ASV NM 537, Tít. VI, Rub. I, Sez. V 17, f. 802.
} 
Era calumniosa hacia los nuncios, queriendo indicar que sus relaciones y trato con las potestades adolecían de una flaqueza criminal. El artículo daba a entender que eran los gobernantes los que tenían poder de influir en el gobierno de la Iglesia. Propagaba la insubordinación contra los Prelados y apartaba a los católicos de la obediencia a las enseñanzas pontificias. Ya en otras ocasiones había tenido que llamar la atención y condenar artículos publicados en ella, como había sucedido a finales de 1884 cuando atacó a los obispos y a la Santa Sede. Entonces Monescillo denunció a los periódicos que habían publicado una versión acomodada a sus intereses de la Immortale Dei. Esto no era lo que habían pretendido los obispos reunidos en Madrid, cuando firmaron el mensaje de adhesión al Papa. La prensa católica no podía erigirse como juez de doctrinas, papel que correspondía a los obispos ${ }^{60}$.

Salió en defensa de la revista otro periódico carlista, La Lealtad, que se definía como periódico católico y órgano oficial del partido carlista, llamándose a sí mismo íntegro ${ }^{61}$. Settier, director de La Ilustración popular y económica y autor del artículo condenado, escribió una serie de cartas justificando su actuación. Publicó en primer lugar la condena del obispo, a continuación insertaba dos cartas, en las que ponía en duda la autenticidad de la condena, pues ésta se había publicado en todos los periódicos menos en los católicos. Afirmaba que no podía rectificar su postura, ya que no se le había indicado qué debía rectificar. Además daba cuenta de su entrevista con Monescillo. El arzobispo, según Settier, habría alabado la labor de la revista, afirmando que la recomendaría en el próximo número del Boletín eclesiástico ${ }^{62}$.

Monescillo informó a Rampolla de su entrevista con Settier. Había prometido someterse al decreto y presentar a la censura eclesiástica los artículos. Sin embargo, Monescillo dudaba que lo llevase a cabo ${ }^{63}$. Acusaba a los instigadores de febronianos calumniadores, aunque Settier era sólo un intermediario. Él se encargaba de escribir los artículos, pero había otros que los inspiraban ${ }^{64}$. Hizo falta una nueva condena de la revista para que ésta se sometiera a la autoridad episcopal ${ }^{65}$.

El nuncio aprobó la decisión de Monescillo, de otra forma hubieran conti-

60 «Nueva condenación de la Ilustración Popular y Económica de Valencia», La Cruz, 1 (1886), 313-314. Una copia de la misma se encuentra en ASV NM 537, Tít. VI, Rub. I, Sez. V 17, f. 765-766.

61 Monescillo-Rampolla, 3 marzo 1886. ASV NM 537, Tít. VI, Rub. I, Sez. V 17, f. 806.

62 «Peligro para la Iglesia católica», La Ilustración popular económica de Valencia. Revista católica de Ciencias, Artes e Industria, Año XVI, 10 de marzo de 1886, n. ${ }^{\circ}$ 597, pp. 113-117.

63 Monescillo-Rampolla, 16 marzo 1886. ASV NM 537, Tít. VI, Rub. I, Sez. V 17, f. 808. Rampolla felicitó a Monescillo por su actuación. Rampolla-Monescillo. Minuta, 17 marzo 1886. ASV NM 537, Tít. VI, Rub. I, Sez. V 17, f. 810.

64 Monescillo-Rampolla, 24 marzo 1886. ASV NM 537, Tít. VI, Rub. I, Sez. V 17, f. 812rv.

65 «Contradicción oficial de la relación capciosa infiel y arbitraria que se hace en la "Ilustración Popular y Económica", de Valencia, de la conducta de su director y condenación de dicha revista», $L a$ Cruz, 1 (1886), 400-407. 
nuado con los ataques al episcopado ${ }^{66}$. Sin embargo, Settier remitió los artículos y la información sobre el proceso de Monescillo al Secretario de la Congregación de Asuntos Eclesiásticos Extraordinarios. Fue rechazado su recurso y toda la documentación fue enviada al nuncio ${ }^{67}$.

Junto a La Tesis de Salamanca y a La Ilustración popular y económica de Valencia, Mateos Gago publicó los días 19 y 21 de enero una serie de artículos en contra de lo dispuesto por León XIII en la Cum multa sobre la prensa católi$\mathrm{ca}^{68}$. Atacaba la actuación de los obispos, añadiendo que, por denunciar esto, había recibido la bendición apostólica. Impedía con esta afirmación la eficacia de cualquier actuación de los obispos ${ }^{69}$.

El periódico La Fidelidad de Burgos, reprodujo unos artículos de Mateos Gago. Estos ataques diarios iban no sólo contra los obispos, sino también contra la Santa Sede, pues atacaba al secretario de la nunciatura, Giacomo della Chie$\mathrm{sa}^{70}$. El nuncio comunicó al arzobispo de Burgos, Manuel Fernández de Castro, que ya había notificado al Vicario Capitular de Sevilla - ya que Sevilla se encontraba en sede vacante- las acusaciones que estaba haciendo el Diario de Sevilla, para que le llamara la atención y pusiera los medios adecuados para impedirlo $^{71}$. Por su parte Fernández de Castro condenó al periódico burgalés, que se retractó y retiró el título de prensa católica dedicándose sólo a la lucha política ${ }^{72}$.

Rampolla notificó al Vicario Capitular de Sevilla las denuncias de los obispos contra el Diario de Sevilla. No sólo estaba poniendo en cuestión la autoridad episcopal, sino que además había reproducido un artículo de El Progreso, órgano del partido zorrillista donde se criticaba la actuación de los obispos durante el funeral del Rey ${ }^{73}$. El Vicario de Sevilla prometió llamar la atención del director e informó también que el periódico publicaba un nuevo artículo contra el obispo de Salamanca por su actuación contra La Tesis ${ }^{74}$. Sin embargo, pocos

66 Rampolla-Monescillo. Minuta, 26 marzo 1886. ASV NM 537, Tít. VI, Rub. I, Sez. V 17, f. 816.

6769917 Jacobini-Rampolla, 6 abril 1887. ASV NM 537, Tít. VI, Rub. I, Sez. V 17, f. 790.

${ }^{68}$ La disidencia de una parte de la prensa católica y las divisiones que provocaban entre los católicos, venían preocupando al Papa y al nuncio en España desde la peregrinación nacional a Roma de 1882. La consecuencia fue la publicación de la Cum Multa ( 8 de diciembre de 1882) y la circular de la nunciatura del 30 abril de 1883. Cfr. C. RoBles MuÑz, «La prensa y las divisiones de los católicos en la Restauración», Hispania Sacra, 40 (1988), 437-453.

69 Martínez Vigil-Rampolla, 3 febrero 1886. ASV NM 537, Tít. VI, Rub. I, Sez. V 16, ff. 736-737.

70 Fernández de Castro-Rampolla, 25 febrero 1886. ASV NM 537, Tít. VI, Rub. I, Sez. V 18, ff. 856-857.

71 Rampolla-Fernández de Castro. Minuta, 26 febrero 1886. ASV NM 537, Tít. VI, Rub. I, Sez. V 18, f. 858.

${ }^{72}$ Fernández de Castro-Rampolla, 7 marzo 1886. ASV NM 537, Tít. VI, Rub. I, Sez. V 18, ff. 862863.

73 Rampolla-Vicario Capitular Sevilla. Minuta, 24 febrero 1886. ASV NM 537, Tít. VI, Rub. I, Sez. V 18, ff. 838-839.

74 Vicario Capitular Sevilla-Rampolla, 27 febrero 1886. ASV NM 537, Tít. VI, Rub. I, Sez. V 18, ff. $840-841$.

Hispania Sacra, Legalidad y conflictos, 58

117, enero-junio 2006, 171-222, ISSN: 0018-215-X 
días después llegaban a la nunciatura las rectificaciones hechas por Mateos Gago $^{75}$. Pero a Rampolla los comentarios que el periodista hacía a continuación de las rectificaciones, no le parecían hechos de buena $\mathrm{fe}^{76}$.

En un nuevo artículo, Mateos Gago arremetió contra Monescillo. El Vicario de Sevilla comunicaba al nuncio que Mateos Gago estaba preparando un memorándum para enviarlo al Papa y obligarle a que le diera la razón. El Vicario por su parte le había escrito pidiendo una nueva retractación ${ }^{77}$. En la entrevista que el director del Diario de Sevilla tuvo con el Vicario de la diócesis puso de manifiesto su decepción por la actuación de Monescillo en Valencia. Colaborador con Gago en otro periódico, habían compartido las mismas ideas ${ }^{78}$.

Pocos días después el periódico sevillano suspendía su publicación ${ }^{79}$. El Vicario de Sevilla había pedido a Mateos Gago que terminara con las críticas a los obispos, de otra forma la Santa Sede mandaría una condena más dura. La respuesta fue el cierre del periódico. Gago no respondió a las invitaciones que le hacían periódicos de Madrid ${ }^{80}$. Abandonaba la lucha política en el momento más crítico. El Siglo Futuro hizo una alabanza del periodista sevillano. Sus doctrinas contra el protestantismo, el liberalismo y sus ataques a los mestizos eran los de la España católica ${ }^{81}$.

El periódico, sin embargo, regresó una semana después ${ }^{82}$. Mateos Gago escribió a Rampolla exponiendo su postura contra el obispo de Salamanca, recogida ya en el Diario de Sevilla. Cámara había utilizado el Boletín de la diócesis para atacar a algunos periodistas de Salamanca. Gago salió en su defensa, lo que provocó una nueva intervención del obispo diciendo que sus artículos eran de perniciosa influencia. Ahora volvía a atacarlo en una nueva pastoral. Por tanto, pedía al nuncio permiso para responder a las acusaciones del obispo ${ }^{83}$. Rampolla contestó por medio del Vicario Capitular de Sevilla. Prohibía a Mateos Gago la publicación de un nuevo artículo que continuara con la polémica. En

\footnotetext{
75 Vicario Capitular Sevilla-Rampolla, 2 marzo 1886. NM 537, Tít. VI, Rub. I, Sez. V 18, f. 842.

76 Rampolla-Vicario Capitular Sevilla. Minuta, 3 marzo 1886. ASV NM 537, Tít. VI, Rub. I, Sez. V 18 , f. 844.

77 Vicario Capitular Sevilla-Rampolla, 6 marzo 1886. ASV NM 537, Tít. VI, Rub. I, Sez. V 18, ff. 848-849. Una copia de la carta del Vicario de Sevilla a Mateos Gago: Copia. Vicario Capitular-Mateos Gago, 6 marzo 1886. ASV NM 537, Tít. VI, Rub. I, Sez. V 18, f. 850.

78 Vicario Capitular Sevilla-Rampolla, 9 marzo 1886. ASV NM 537, Tít. VI, Rub. I, Sez. V 18, f. 851 .

79 Vicario Capitular Sevilla-Rampolla, 21 marzo 1886. ASV NM 537, Tít. VI, Rub. I, Sez. V 18, f. 854 .

80 Vicario Capitular de Sevilla-Rampolla, Sevilla 29 de marzo 1886. ASV NM 537, Tít. VI, Rub. I, Sez. V 18, f. 854rv.

81 «El Diario de Sevilla», El Siglo Futuro (23 marzo 1886), 1.

82 «Una buena noticia», El Siglo Futuro (31 marzo 1886), 1.

83 Mateos Gago-Rampolla, 10 abril 1886. ASV NM 537, Tít. VI, Rub. I, Sez. V 16, ff. 750-751.
} 
caso de tener alguna acusación contra el obispo de Salamanca podría acudir directamente a la Santa Sede, pero no emplear la prensa ${ }^{84}$.

El Vicario cumplió lo mandado por el nuncio. Se entrevistó con Gago y le expuso el contenido de la carta de Rampolla. El periodista se defendió afirmando que había escrito al nuncio para defenderse de los ataques. No era suficiente. El Vicario insistió para que prometiera acatar lo ordenado y cesar en la polémica. Así lo hizo. Pidió a cambio que se le dejara insertar en el periódico un suelto ${ }^{85}$. El Vicario lo remitió a Rampolla que dio permiso para su publicación ${ }^{86}$. El 24 de abril Mateos Gago enviaba una carta al Diario de Sevilla. Acataba la orden de no seguir la polémica con el obispo de Salamanca ${ }^{87}$.

\subsubsection{Tensiones en el partido carlista}

La ofensiva integrista contra los obispos tuvo su epicentro en distintas provincias. Eran periódicos regionales los que atacaban al episcopado. Sin embargo, todo apuntaba que detrás estaba Ramón Nocedal y El Siglo Futuro. ¿Qué estaba sucediendo?

La guerra de la prensa integrista contra los obispos era la consecuencia de la división interna del partido carlista. Según informaba Rampolla, cada día era mayor la fractura entre integristas y moderados ${ }^{88}$. Desde hacía un mes se estaba produciendo una escisión de los más intransigentes, capitaneados por Ramón Nocedal. Los motivos se remontaban al tiempo en que el duque de Madrid había encomendado la dirección del partido en España a Cándido Nocedal, padre del director de El Siglo Futuro. Esto provocó luchas sobre la ideología que debía conducir al partido. Cándido Nocedal había levantado la bandera del absolutismo, pretendiendo acudir a medios revolucionarios para alcanzar el poder. Llegó al extremo de atacar al episcopado, cuando éste se manifestó contrario a sus procedimientos, valiéndose del clero y de la población que quería defender los principios de la religión católica y con la excusa de salvar la Religión de cualquier contagio de liberalismo.

\footnotetext{
${ }^{84}$ Rampolla-Vicario Capitular de Sevilla. Minuta, 13 de abril de 1886. ASV NM 537, Tít. VI, Rub. I, Sez. V 16, f. 752.

${ }^{85}$ Vicario Capitular-Rampolla, 15 abril 1886. ASV NM 537, Tít. VI, Rub. I, Sez. V 16, ff. 754755. f. 756.

${ }^{86}$ Rampolla-Vicario Capitular. Minuta, 17 abril 1886. ASV NM 537, Tít. VI, Rub. I, Sez. V 16,

87 Copia. Mateos Gago-Director Diario de Sevilla, 24 abril 1886. ASV NM 537, Tít. VI, Rub. I, Sez. V 16, f. 712 .

88467 Rampolla-Jacobini, 19 marzo 1886. ASV SS 249 (1886), 2, ff. 120-127. Respuesta de Jacobini: 66231 Jacobini-Rampolla, 27 marzo 1886. ASV NM 534, Tít. V, Rub. II, Sez. III 20, f. 583.
}

Hispania Sacra, Legalidad y conflictos, 58

117, enero-junio 2006, 171-222, ISSN: 0018-215-X 
La consecuencia de esto fue la división del partido en dos grupos. Uno de ellos, cuyo jefe era Nocedal, buscaba la destrucción del orden establecido para construir sobre las ruinas una nueva Monarquía absoluta y católica. En torno a esta posición se situó el clero rural. Otro grupo, inferior en número, quería que el duque de Madrid siguiera las directrices de los obispos. Se inclinaban por una política más discreta y tolerante, y menos pesimista. Junto a esto, las envidias y las ambiciones personales hicieron que creciera la división entre los dos grupos. Tirios y troyanos crearon sus propios órganos de difusión. El Siglo Futuro, de los más integristas, y $\mathrm{La} \mathrm{Fe}$ de los moderados ${ }^{89}$.

Cándido Nocedal había intentado que el episcopado se enfrentara a la Monarquía, por medio de algunos actos que provocaran la ruptura de relaciones entre España y la Santa Sede, sin conseguirlo. La Immortale Dei consiguió desarmar los argumentos de los integristas; y la declaración de los obispos hecha en Madrid puso en evidencia los intentos de Nocedal de mezclar las cuestiones políticas y religiosas, subordinando los intereses de la segunda a favor de las ambiciones políticas. A esto había que unir la muerte de Cándido Nocedal.

Dos problemas se presentaron entonces a la facción integrista del partido. Tenían que buscar un hombre fuerte que sustituyera a Cándido Nocedal y que al mismo tiempo tranquilizara los ánimos de unos y otros, haciendo retornar a las filas del partido a aquellos que ante la postura firme de la Santa Sede y del episcopado estaban abandonando la lucha para optar por la legalidad. Las opciones eran dos. Unos querían una continuidad con la política seguida hasta el momento. En este caso se postulaba Ramón Nocedal, como el hombre fuerte del partido en España. Otros, como el marqués de Cerralbo, amigo personal del duque de Madrid, querían un cambio que uniera a las distintas fracciones del partido. La solución tomada por D. Carlos fue asumir la dirección de sus asuntos en España valiéndose de distintas personas, según las circunstancias. La decisión tranquilizó los ánimos, al menos por el momento. El partido estaba aparentemente reconciliado, pero continuaron las divisiones internas, de un modo más marcado que antes.

En este estado de cosas, Nocedal comenzó la campaña contra el episcopado con el fin de frenar los efectos que el documento firmado por los obispos en Madrid estaba logrando. El Siglo Futuro comenzó a publicar una serie de artículos en los que ponía de manifiesto la gran influencia que su partido tenía entre la población. Era la táctica seguida desde 1876. El carlismo tenía que ampliar su base social y con este fin, Nocedal hizo una serie de viajes a Cataluña

89 Las divisiones en el seno del carlismo venían de atrás. Después de la última derrota militar sufrida por los carlistas, el partido se dividió en dos tendencias claras. La primera encabezada por Cándido Nocedal y su hijo Ramón. La segunda por Alejandro Pidal. Ya entonces esta división afectó a los católicos en general y a los obispos en particular. Cfr. C. RoBles MuÑOZ, «La fractura de la unidad política de los católicos españoles (1881-1884)», Burgense, 29 (1988), 210-228. 
donde tuvo reuniones de carácter político. El apoyo y entusiasmo con el que fue recibido, le servían para demostrar que él podía conseguir el favor de la opinión pública católica para el pretendiente ${ }^{90}$.

En el viaje, Nocedal puso de manifiesto su adhesión a la Immortale Dei, al menos en los discursos pronunciados en los Círculos Católicos. No hizo lo mismo, en cambio, en las conversaciones privadas, según las denuncias que llegaban a Rampolla. Nocedal animaba a resistir a la autoridad eclesiástica y a la Santa Sede.

La prensa integrista comenzó entonces a atacar a los obispos y al mismo nuncio. El primero en sufrir los ataques fue el P. Cámara, obispo de Salamanca. Poco después se acusó al secretario de la nunciatura. En una conversación privada había contradicho el documento del Secretario de Estado sobre la autoridad de los nuncios. Un periódico republicano, donde escribía un antiguo redactor de El Siglo Futuro, se encargó de difundir la calumnia. La información fue desmentida en distintos periódicos, menos en los llamados católicos, que se encargaron de seguir difundiéndola con palabras de desprecio hacia Rampolla. El principal promotor había sido Mateos Gago a través del Diario de Sevilla. Su artículo lo reprodujo la prensa de Burgos, Salamanca y Valencia. Las condenas hechas por el episcopado consiguieron que el duque de Madrid reaccionara.

Los artículos de la prensa integrista estaban alejando a los obispos del partido carlista. Había que atajar la polémica, ya que existía peligro de abrir una brecha entre los obispos y aquellos que quería hacer suya la causa católica. Con este fin, Navarro Villoslada, encargado ahora de los negocios del duque de Madrid y antiguo director del Pensamiento español, escribió en nombre de D. Carlos una carta a los dos principales periódicos tradicionalistas, La Fe y El Siglo Futuro. El primero publicó la carta con cierta celeridad. Navarro Villoslada pidió que cesara la polémica con los obispos. La Iglesia era maestra también en aquello que se refería a las cuestiones de orden político y había que seguir sus enseñanzas ${ }^{91}$.

El Siglo Futuro, en cambio, preguntó por la autoridad de la carta. Dijo que le habían dado libertad para publicarla o no, pero ante las acusaciones que le hacía $\mathrm{La} \mathrm{Fe}$, optó finalmente por su publicación ${ }^{92}$. Navarro Villoslada escribió a Nocedal, indicando que era obligación de todos los periódicos carlistas publicar la carta del día 12 de marzo ${ }^{93}$. El 27 de ese mes El Siglo Futuro se sometía a las indicaciones dadas por el duque de Madrid. Obedecería a los obispos en el terreno religioso. En todo aquello que entraba en el ámbito de la política, sólo a la

\footnotetext{
90467 Rampolla-Jacobini, 19 marzo 1886. ASV SS 249 (1886), 2, ff. 120-127.

91 «Documento importante», La Fe (12 marzo 1886), 1.

92 «La carta del señor Navarro Villoslada», El Siglo Futuro (16 marzo 1886), 1.

93 «Carta de Navarro Villoslada al Siglo Futuro», El Siglo Futuro (18 marzo 1886), 2.
} 
potestad temporal le incumbía dar órdenes. La carta no significaba que hubiese que transigir con el enemigo; en los momentos de crisis social no se puede oscurecer la verdad. Este incidente era una advertencia del peligro que conllevaba la polémica y un llamamiento a la armonía y paz con los obispos ${ }^{94}$.

El fin principal de la carta había sido quitar cualquier recelo que los obispos pudieran tener contra los carlistas. Sin embargo, consiguió el efecto contrario. La división estaba aumentando y Nocedal se apartaba cada vez más del duque de Madrid suscitando una polémica que éste no deseaba. D. Carlos entonces cedió y hechó marcha atrás. Las circunstancias podían cambiar, había que evitar el enfrentamiento y mantener la unidad del partido, por tanto había que mantener la libertad política frente a las intervenciones episcopales ${ }^{95}$.

Tampoco en esta ocasión consiguió el resultado esperado. Abiertamente se admitía la llamada de atención de D. Carlos, pero en realidad los problemas aumentaron y las disensiones crecieron, principalmente por parte de Nocedal $^{96}$. Ahora bien, la rectificación del pretendiente sí consiguió la dimisión de Navarro Villoslada, el 25 de abril, «por motivos de salud» ${ }^{97}$.

\subsection{La amenaza contra la legalidad}

Coincidiendo con la muerte de Alfonso XII hubo amenazas de levantamientos carlistas en algunas provincias españolas. La noticia, sin embargo, fue desmentida por El Siglo Futuro. Era una maniobra del gobierno para unir las fuerzas liberales ante el posible peligro ${ }^{98}$. No sería la sublevación el medio empleado por los carlistas para llegar al poder. Esperarían hasta ver cómo se desarrollaban los acontecimientos. D. Carlos no creía en la estabilidad política de la regencia. No resistiría los ataques de los republicanos. Y cuando estos llegasen,

\footnotetext{
94 «Documento oficial», El Siglo Futuro (27 marzo 1886), 1.

95 «Antes de concluir, haré observar a V. que es preciso evitar todo equívoco en lo que digo respecto a los Obispos y que la declaración de Villoslada aprobada por SM. No supone ningún modo que los Obispos puedan mandarnos en política. No: nada de eso, y si se propasara alguno en ese terreno no hay que obedecerla. En lo único que se reconoce la autoridad y el magisterio episcopal es en la doctrina y en la moral, y lo único que se ordena a nuestros periódicos es que no invadan ese terreno y no molesten a los prelados con discusiones metafísicas o teológicas, pero repito una vez más que si un obispo se permitiera darnos órdenes en política, no se discutiría con él, pero tampoco se le obedecería»: Copia. Melgar-Cavero. 19 marzo 1886. ASV NM 534, Tít. V, Rub. II, Sez. III 20, ff. 597-598.

96472 Rampolla-Jacobini. Minuta, 31 marzo 1886. ASV NM 534, Tít. V, Rub. II, Sez. III 20, ff. 591-592.

La escisión culminaría poco tiempo después. Con el Manifiesto de Burgos nacía el partido integrista. Cfr. A. Martínez Esteban, «La opción política del clero. El traslado del Obispo de Vitoria, Miguel y Gómez», Scriptorium Victoriensis, 52 (2005), 165-168.

97 El Siglo Futuro (30 abril 1886), 1.

98 «La eterna maniobra», El Siglo Futuro (25 noviembre 1885), 1.
} 
entonces sería el momento de presentarse como salvador de la nación y del orden ${ }^{99}$.

El partido carlista quería ser el partido del orden y la estabilidad frente a la confusión y la anarquía que produciría la crisis política que se avecinaba. Mientras todos los demás partidos hacían transacciones con los liberales para sostener la Monarquía, ellos, el partido tradicionalista, serían los defensores de la antigua España ${ }^{100}$.

Se adhirió a este pensamiento un sector del clero. El gobierno quiso evitar que tomaran partido por los carlistas, por eso esperaba que la unión del episcopado en torno a la Reina consiguiera frenar el movimiento de atracción hacia el carlismo. Hubo denuncias contra clérigos que se pusieron contra la legalidad. El magistral de la Catedral de Santiago pronunció una homilía en la que atacó duramente a los Reyes ${ }^{101}$. Eran exageraciones de la prensa liberal. Payá, arzobispo de Santiago, lo disculpó ante el nuncio y el ministro de Gracia y Justi$\operatorname{cia}^{102}$.

La situación de inestabilidad que vivía el país hacía presagiar que el gobierno Sagasta no iba a tener fácil atajar las pretensiones de republicanos y carlistas. Tenía que conciliar posturas, al menos entre un sector republicano que había entrado dentro del juego constitucional. Ahora no podía permitir que se extremaran las posturas. Sabía que republicanos e izquierdistas exigirían la puesta en marcha del programa liberal. Sólo de esta forma evitaría que estos salieran del terreno legal ${ }^{103}$.

Emilio Castelar rechazó la posibilidad de una revolución armada que trajera la República. Ésta llegaría, pero no como pretendía D. Carlos. El camino sería lento, pacífico y legal, al margen de revoluciones populares y golpes militares. Sería una República conservadora, donde se defendieran las grandes aspiraciones de la democracia, los derechos individuales, el sufragio universal, el juicio por jurados, la libertad religiosa. No habría más guerras civiles. Castelar se desvinculaba de una posible unión de republicanos y carlistas con el fin de derrocar la Monarquía. La última guerra carlista no fue una lucha por la sucesión sino por la defensa de la libertad frente a la intolerancia religiosa y la unidad católica en España ${ }^{104}$.

Había otro sector. Los republicanos zorrillistas no estaban por la vía legal. Zorrilla y los carlistas se ayudarían mutuamente para derrocar el sistema mo-

\footnotetext{
99 «La libertad y el orden», El Liberal (30 noviembre 1885), 1.

100 «La transacción», El Siglo Futuro (9 diciembre 1885), 1.

101 Rampolla-Payá. Minuta, 13 diciembre 1885. ASV NM 533, Tít. V, Rub. I, Sez. III 1C, f. 745.

102 Payá-Rampolla, 15 diciembre 1885. ASV NM 533, Tít. V, Rub. I, Sez. III 1C, f. 747.

103 «Lo que debe ser», El Liberal (5 diciembre 1885), 1.

104 «Nuevas declaraciones del Sr. Castelar», El Liberal (9 diciembre 1885), 1.
} 
nárquico ${ }^{105}$. Sólo el acuerdo entre los dos partidos dinásticos podía salvar la situación y dar tranquilidad al país. Cánovas tenía que evitar mayores disidencias en su partido una vez producida la escisión de Romero Robledo. Sagasta debía presentar una política más liberal que atrajera a demócratas como Martos, Castelar o Salmerón. Mientras esto no se produjera cualquier gobierno sería posible, y ahí estarían los antidinásticos ${ }^{106}$.

Sagasta intentaría moderar la postura de los tradicionalistas en las elecciones. El sistema electoral seguido en España permitía al partido del gobierno repartir los votos de acuerdo a sus intereses. La mayoría era siempre para el partido que había recibido el acta de disolución de las Cortes. A partir de aquí se podían repartir los escaños los distintos partidos; aunque el otro partido dinástico tenía la mayoría dentro de la oposición, había un margen de votos para el resto, incluso para los antidinásticos. Esto permitiría a Sagasta dar la victoria al partido carlista en algunas provincias españolas, principalmente en las del norte donde tenía más fuerza. Rampolla dudaba del buen resultado de esta operación. Conocía bien la postura del sector integrista del partido. Esperarían la caída de la actual Monarquía y después, el desastre que provocarían los zorrillistas al subir al poder, algo que según ellos no tardaría mucho en suceder. Ahora bien, las divisiones del propio carlismo hacían esperar que en breve dejaran los intentos de levantamiento armado para descender a la arena parlamen$\operatorname{taria}^{107}$.

La actitud conciliadora de la Regente evitaba el triunfo de cualquier sublevación, aunque Moret manifestó al nuncio la preocupación del gobierno por el peligro de los antidinásticos. Zorrillistas y carlistas se unirían para evitar que la regencia se consolidase. No había muchas esperanzas, como quiso Sagasta, de que los carlistas se incorporasen a las instituciones políticas, antes dejarían que llegase la República. Mientras, hacían provisión de dinero en distintos países de Europa y América y corrían rumores sobre la presencia de D. Carlos en los Pirineos, pero el gobierno no había podido confirmarlo.

Mucho más temible podía resultar Zorrilla. Contaba con apoyo material y moral al otro lado de la frontera. La presencia de radicales en el gobierno francés permitía a los revolucionarios libertad de movimiento. Mientras daba garantías de respeto a la legalidad, estaba favoreciendo las conspiraciones revolucionarias. Había pruebas de ello. Moret indicó a Rampolla que existía una circular secreta dirigida a la policía francesa. Prohibía la intervención en las reuniones de republicanos y carlistas. El gobierno español temía que se estuviera preparando una conspiración zorrillista para demostrar que todavía tenían

105 «Los extremos se tocan», La Época (13 enero 1886), 1.

106 «Consideraciones sobre la situación», El Siglo Futuro (7 enero 1886), 1.

107444 Rampolla-Jacobini, 14 enero 1886. ASV SS 249 (1886), 2, ff. 90-91. 
fuerza. Moret no estaba dispuesto a consentir esto. Las facilidades que el gobierno francés daba a los revolucionarios crearía tensiones entre los dos países y Moret amenazaba con dimitir ${ }^{108}$.

Los carlistas se reunieron en secreto en el norte de España, presididos por el marqués de Sangarrén. Hubo dos posturas enfrentadas. La mayoría pensaba que era el momento de actuar, aprovechando la debilidad del régimen, en inteligencia con los zorrillistas. Otros creían que era mejor esperar el desarrollo de los acontecimientos. Triunfó esta postura gracias a la intervención del canónigo magistral de Vitoria y la buena actuación del obispo. Había que esperar el resultado de una posible reconciliación entre las dos familias con la boda del hijo del duque de Madrid y la Princesa de Asturias ${ }^{109}$. Así lo comunicó El Siglo Futuro a sus partidarios. La actitud de los carlistas era estar expectantes. Una vez más las noticias de los periódicos liberales sobre movimientos carlistas eran falsas. El partido tradicionalista seguía tan vigoroso como en tiempos de Zumalacárregui, pero «... hoy, como siempre, está dispuesto a todo, pero, así como sabe pelear, también sabe obedecer, y hoy le toca esperar tranquilamente» ${ }^{110}$.

Sin embargo, Nocedal no se detuvo en la campaña de propaganda integrista. Durante los viajes que hizo por Cataluña consiguió levantar el ánimo de sus correligionarios. No era el momento de echarse atrás ni cesar en la lucha. Había que esperar, pero no debían permanecer quietos. Fue recibido con gran entusiasmo en los lugares donde pronunció discursos. Consiguió el objetivo. La batalla contra los liberales y los ataques contra el episcopado crecieron por parte de la prensa integrista ${ }^{111}$. Al mismo tiempo, desde círculos integristas romanos quisieron poner en cuestión la política tolerante de León XIII con España. Se dijo que se estaban llevando a cabo acuerdos entre el Vaticano y el partido carlista. Jacobini autorizó a Alejandro Groizard, embajador español ante la Santa Sede, para que desmintiera los rumores ${ }^{112}$. El gobierno nunca les dio crédito. Se fiaba de la sinceridad de las declaraciones de la Santa Sede. Tenía noticias de la protesta que los carlistas habían hecho al Vaticano por la actitud de los obispos, aunque los esfuerzos por obtener una respuesta habían sido inútiles ${ }^{113}$.

108450 Rampolla-Jacobini. Minuta, 30 enero 1886. ASV NM 534, Tít. V, Rub. II, Sez. III 19, ff. 564-567.

109451 Rampolla-Jacobini, 7 febrero 1886. ASV SS 249 (1886), 2, ff. 109-112.

Serían los liberales los que se negarían a este matrimonio. Ya lo habían hecho un año antes, con la muerte del rey. Sería introducir a los varones de la familia real expulsada. «iAl fin los mestizos!», El Imparcial (23 junio 1886), 1.

110 «A los liberales», El Siglo Futuro (16 febrero 1886), 1.

111 «A nuestros amigos», El Siglo Futuro (15 marzo 1886), 1.

112 Copia. Cifra. Groizard-Moret, 6 abril 1886. ASV NM 537, Tít. VI, Rub. I, Sez. V 16, f. 719.

113 Copia. Cifra. Moret-Groizard, 7 abril 1886. 537, Tít. VI, Rub. I, Sez. V 16, f. 720. 
Pero continuaba el apoyo del clero, secular y regular al carlismo. Moret comunicó a Rampolla las noticias del movimiento carlista que se estaba produciendo en la Rioja alavesa. En una nota entregada al ministro se afirmaba que en una reunión carlista en Salvatierra, provincia de Vitoria, estaban presentes los párrocos de Arrizala y el de Zalduenga. Además, algunos jesuitas habían acompañado al marqués de Valdespinos, conocido carlista, durante su visita a Vitoria y a Zumárraga ${ }^{114}$.

El embajador español ante la Santa Sede informó al Secretario de Estado. «Algunos individuos del clero de Álava y Cataluña» y los jesuitas de Vitoria estaban colaborando con los carlistas. Groizard pedía que el Vaticano, por medio del Nuncio, interviniera ante los obispos de Vitoria y las diócesis catalanas «donde por lo visto algunos clérigos atizan y preparan la rebelión» ${ }^{115}$.

La prensa denunció los hechos. Había amenaza de guerra civil en la frontera donde se encontraba en esos momentos el duque de Madrid ${ }^{116}$. Jacobini pidió información a Rampolla. Desde Berlín llegaban a la Santa Sede noticias preocupantes sobre la situación en España. No se podía permitir que el clero tomara partido por alguno de los bandos. Los obispos debían poner orden y evitar cualquier acto de rebeldía por parte del clero ${ }^{117}$. El nuncio se puso en contacto con el obispo de Vitoria ${ }^{118}$. Las noticias sobre la participación del clero no tenían fundamento, incluso el mismo gobierno consideraba exageradas las que llegaban desde Berlín ${ }^{119}$.

Los temores sobre una posible insurrección republicana se confirmaron en el mes de septiembre. El domingo 19 una sublevación militar en el cuartel de San Gil en Madrid proclamó la República ${ }^{120}$. Los sediciosos con un grupo de ciudadanos se habían hecho con el mando del cuartel matando al general Velarde y al coronel Conde de Mirasol. El gobierno consiguió dominar la situación evitando que se extendiera la rebelión. Se detuvo a los jefes del movimiento, entre ellos al general Villacampa ${ }^{121}$.

114 Moret-Rampolla, 21 junio 1886. ASV NM 534, Tít. V, Rub. II, Sez. III 20, f. 605.

115 Groizard-Jacobini, 22 junio 1886. ASV SS 249 (1886), 2, f. 169.

Unos años más tarde volvieron las acusaciones contra el clero vasco y los jesuitas. En esta ocasión las denuncias arrastrarían al obispo de Vitoria, Miguel y Gómez, provocando su traslado de diócesis. Cfr. A. Martínez Esteban, «La opción política del clero. El traslado del Obispo de Vitoria, Miguel y Gómez», Scriptorium Victoriensis, 52 (2005), 170-181.

116 «Los carlistas», La Época (22 junio 1886), 1.

11767229 Jacobini-Rampolla, 23 junio 1886. ASV NM 534, Tít. V, Rub. II, Sez. III 20, f. 599.

118 Rampolla-Miguel y Gómez, 23 junio 1886. ASV NM 534, Tít. V, Rub. II, Sez. III 20, f. 608.

119 Cifra. Rampolla-Jacobini, 27 junio 1886. 534, Tít. V, Rub. II, Sez. III 20, f. 603.

120530 Rampolla-Jacobini, 20 septiembre 1886. ASV SS 249 (1886), 3, ff. 117.

121 Fue la decisión del gobierno francés de cortar la subvención a los refugiados republicanos españoles, lo que obligó a Ruiz Zorrilla a promover el levantamiento. Cfr. E. GonZÁlez CALleJA, La razón de la fuerza. Orden público, subversión y violencia política en la España de la Restauración (1875-1917), Madrid, 1998, pp. 125-144. 
El gobierno tuvo conocimiento de los planes revolucionarios con antelación. Un alto personaje pasó noticia al ministro de la Gobernación y éste al de Guerra. La noche de la sublevación uno se encontraba en la cama y el otro en el teatro. Ninguno de los dos había tomado las medidas oportunas ${ }^{122}$. El ministro de la Guerra, general Joaquín Jovellanos, no actuó con la celeridad y firmeza que cabría esperar. Según Moret, cerraba los ojos ante los militares que conspiraban abiertamente. La indisciplina del ejército estaba provocando el descrédito de España en Europa. Pero, a pesar del miedo del gobierno, el levantamiento no fue seguido. Los partidos extralegales no conseguían imponerse. La nación estaba cansada de luchas y deseaba la paz. Sagasta tenía que concentrar todos los esfuerzos en procurar el orden interno del país y reunir en torno a la Monarquía a todos los elementos de orden. No había que intentar reformas peligrosas ni tocar cuestiones delicadas en el terreno religioso que animasen a unos y a otros a tomar posiciones contrarias a la legalidad ${ }^{123}$.

Consecuencia del intento de sublevación fue la petición a Francia de la expulsión de Zorrilla. Para asegurar que el gobierno la aceptara, Moret escribió a los embajadores españoles en países con monarquías. Quería el concurso de todos ellos para conseguir que cesara el apoyo francés a las conspiraciones republicanas ${ }^{124}$.

Ahora bien, los efectos del levantamiento militar podían ir más allá. El gobierno estaba dispuesto a aplicar las medidas disciplinares con todo su rigor. Esto podría tener graves consecuencias. La hija de Villacampa y el director de El Imparcial y diputado liberal acudieron a Rampolla para que solicitara la mediación del Papa en el indulto al general. El político señaló que la situación del gobierno era delicada y podría abrir una crisis ministerial si aplicaba la pena máxima. La Reina, en su primer año de regencia, se haría odiosa si no adoptaba la iniciativa del indulto. Así lo esperaba la guarnición militar de Madrid y los republicanos que estaban esperando cómo se resolvía la situación, ya que no tendrían reparo en intentar una nueva sublevación o incluso llegar a atentar contra la Reina.

El nuncio hizo la petición a título personal. No podía comprometer la actuación de la Santa Sede, ni ésta debía intervenir en cuestiones de política interna. Informó antes al gobierno para asegurarse de que la mediación no fuese mal vista. En el Consejo de ministros, presidido por la Reina, se acordó una audiencia de ésta a Rampolla. La Reina quiso confirmar la noticia sobre la apelación que la hija y los amigos de Villacampa habían hecho a Roma. El nuncio contestó afirmativamente. Desde el Vaticano no podían hacer nada por deferencia a la

\footnotetext{
122539 Rampolla-Jacobini, 10 octubre 1886. ASV SS 249 (1886), 3, ff. 143-147.

123 531 Rampolla-Jacobini, 23 septiembre 1886. ASV SS 249 (1886), 3, ff. 119-121.

124 Copia. Moret-Embajadores Berlín, Viena, San Petersburgo, Roma y Londres, 25 septiembre 1886. ASV SS249 (1886), 3, ff. 131-132.
} 
Regente. Rampolla aprovechó para desmentir ante la Reina las acusaciones contra algunos jesuitas. Era necesario atraerse el favor de la Compañía, pero ante imprudencias de algunos padres, León XIII había dado instrucciones a Antón Anderledy, Vicario General ${ }^{125}$, para que los religiosos se abstuvieran de participar en debates políticos ${ }^{126}$.

La cuestión del indulto dividió al gobierno. En el Consejo se decidió aplicar la pena máxima. La noticia se trasmitió a los medios, filtrada por el secretario de Sagasta, partidario del indulto, para conseguir la pacificación del país. De esta forma se obligó a la Reina a indultar a los detenidos ${ }^{127}$. Sagasta consiguió salvar la situación, pero no el gobierno. Presentaba la dimisión a la Reina y el 9 de octubre formaba nuevo gabinete ${ }^{128}$.

\section{3. «LA GRAN BASE DE LA CONCORDIA [...] LA TRANQUILIDAD EN EL ORDEN» 129}

Así definiría el obispo de Salamanca, el P. Cámara, el estado en el que se encontraban las relaciones entre la Iglesia y el gobierno Sagasta en esta primera etapa de la regencia. El camino seguido por unos y otros era la tranquilidad en el orden, de esta forma se conseguía la paz necesaria para el progreso del país.

Al mismo tiempo, el nacimiento de Alfonso XIII aseguraba la Monarquía y desbarataba los posibles ataques contra el orden constitucional de carlistas y republicanos. La regencia se abría camino en medio de las dificultades gracias a la labor del gobierno Sagasta que dio una base sólida a las instituciones vigentes. Ahora llegaba el momento de poner en marcha los proyectos de la política liberal, sin que se rompiera la concordia alcanzada con la Iglesia.

125 Antón María Anderledy (1819-1892) fue el vigésimo tercer General de la Compañía de Jesús. Ejerció los cargos de Vicario General desde 1883 hasta el 4 de marzo de 1887, fecha de la muerte del P. Beckx, General anterior y momento en el que Anderledy asumió la dirección de la Compañía. Cfr. F. Strobel, «Anderledy, Antonio María», en Ch. E. O’Neill-J. M. ${ }^{a}$ Domínguez (dirs.), Diccionario Histórico de la Compañía de Jesús. Biográfico-Temático, vol. II, pp. 1675-1676.

126534 Rampolla-Jacobini, 2 octubre 1886. ASV SS 249 (1886), 3, ff. 135-139. Sobre las acusaciones contra los jesuitas y las instrucciones del General: Cfr. M. Revuelta GonzÁlez, La Compañía de Jesús en la España Contemporánea. Tomo II. Expansión en tiempos recios (1884-1906), Madrid, 1991, pp. 295-299.

127 El Imparcial (6 octubre 1886), 1.

128539 Rampolla-Jacobini, 10 octubre 1886. ASV SS 249 (1886), 3, ff. 143-147.

129 DSS, 51 (21 febrero 1889), 828-843. 


\subsection{El nacimiento de Alfonso XIII}

Las tensiones creadas por los intentos de los partidos antidinásticos desaparecieron, al menos en parte, el 17 de mayo de 1886. Este día nacía Alfonso XIII, con lo que se despejaban las dudas sobre el futuro de la Monarquía española.

De nuevo Rampolla y León XIII jugarían un papel importante en el reconocimiento del futuro Monarca. La relación de España con la Santa Sede, después de la muerte de Alfonso XII, había cambiado. El gobierno español y la Regente reconocían el importantísimo papel que el Papa había jugado en la reconciliación de la Iglesia con las civilizaciones modernas. Los hechos demostraban que ambas potestades se podían unir con un mismo fin, buscar el bien y la concordia entre los pueblos. La carta conjunta del episcopado había supuesto el final de las pretensiones carlistas de subir al trono. Sólo les quedaba o la rebeldía o incorporarse a los conservadores. Un sector optó por lo primero, uniéndose a los republicanos en la lucha por el poder. Tenían el apoyo de una parte del clero, sobre todo en el norte de España. Algo sobre lo que había que insistir ante el Vaticano. Pero habría reconciliación si el clero y el Estado se unían de cara a las reformas sociales ${ }^{130}$.

Días antes del nacimiento del rey, la Regente pidió al Papa que fuera padrino del futuro Monarca. Era la mejor forma de agradecer todo lo que León XIII había hecho por España ${ }^{131}$. El Papa aceptó y nombró a Rampolla su representante para la celebración del bautizo ${ }^{132}$.

El día del nacimiento fue Sagasta el encargado de presentar al nuevo príncipe, según las costumbres de la Corte. El recibimiento que dio la población fue de gran alegría. En la recepción que hubo a continuación, Rampolla señaló al Presidente del gobierno la importancia que tenía la aceptación, por parte del Papa, del padrinazgo de Alfonso XIII. La noticia sirvió para poner de relieve el apoyo de la Iglesia a la Monarquía ${ }^{133}$.

Una prueba más del apoyo de la Santa Sede a la regencia fue la concesión de la Rosa de oro a la Reina, entregada por Ciriaco María Sancha ${ }^{134}$, obispo de

130 Moret-Groizard, 2 abril 1886. AMAE. Santa Sede H 1739. Santa Sede.

131 Cifra. Rampolla-Jacobini, 4 mayo 1886. ASV NM 533, Tít. V, Rub. I, Sez. I 16, f. 308. Por medio de un despacho fechado el mismo día, Rampolla enviaba una carta de la Reina con la petición al Papa. 488 Rampolla-Jacobini. Minuta, 4 mayo 1886. ASV NM 533, Tít. V, Rub. I, Sez. I 16, f. 325.

13266733 Jacobini-Rampolla, 14 mayo 1886. ASV NM 533, Tít. V, Rub. I, Sez. I 16, f. 327.

Rampolla respondió agradeciendo el nombramiento hecho por el Papa. Cifra, Rampolla-Jacobini, 18 mayo 1886. ASV NM 533, Tít. V, Rub. I, Sez. I 16, f. 310.

133495 Rampolla-Jacobini. Minuta, 18 mayo 1886. ASV NM 533, Tít. V, Rub. I, Sez. I 16, ff. 330-331.

134 Ciriaco María Sancha y Hervas (1833-1909). Licenciado en teología por la Universidad de Salamanca, ocupó la cátedra de moral y dogmática en el Seminario de Osma. Por un enfrentamiento con Ruiz Zorrilla en 1872, entonces ministro de Gracia y Justicia, fue procesado y encarcelado. Después de

Hispania Sacra, Legalidad y conflictos, 58

117, enero-junio 2006, 171-222, ISSN: 0018-215-X 
Ávila y preconizado para la diócesis de Madrid-Alcalá ${ }^{135}$. Todo esto daba a entender que las relaciones entre el gobierno liberal de Sagasta y la Iglesia estaban en uno de sus mejores momentos. Se estaba demostrando que «... las instituciones actuales, son perfectamente compatibles con la existencia de la armonía y de la concordia entre la Iglesia y el Estado» ${ }^{136}$.

La normalización de las relaciones tendría que pasar por las negociaciones en puntos importantes. Uno de ellos sería la ley de instrucción pública que Montero Ríos pensaba presentar a las Cortes. Éste había anulado el Real decreto de Alejandro Pidal en un momento en el que era necesario atraer a todos los elementos de orden. Así se lo indicó Rampolla a la Regente. La Reina quitó importancia al hecho. El gobierno dejaría a la Iglesia el derecho a designar los profesores de religión y moral en las escuelas. Esto, en opinión del nuncio, no era suficiente para la enseñanza superior universitaria. Había que impedir que el ministro llevara adelante su proyecto ${ }^{137}$.

El gobierno no tenía intención de poner en peligro las buenas relaciones con la Iglesia. La religión constituía un medio importante para combatir el socialismo, ya sea en las cuestiones de orden público como en la educación de la juventud. Era consciente de la fuerza moral que ésta podía tener en España. Las persecuciones sufridas en otro tiempo no se volverían a repetir. Los partidos políticos habían visto en la actitud de los obispos hacia la regencia una prueba segura de paz y tranquilidad. Sabían que en la Iglesia podían encontrar un apoyo para sostener el orden y un poderoso aliado en las cuestiones internacionales. Así se lo indicó Moret a Rampolla, quien le confió también la existencia de un proyecto para transferir todos los asuntos religiosos del ministerio de Fomento al de Gracia y Justicia. Esto permitiría quitar de las manos a Montero Ríos las posibles reformas sobre la enseñanza religiosa y encargárselas a Alonso Martínez, más respetuoso con las creencias religiosas de los españoles ${ }^{138}$.

El nacimiento de Alfonso XIII fue muy bien recibido por la población y fue,

su salida de prisión sería nombrado obispo auxiliar de Toledo. De donde pasó a Ávila y de aquí a Madrid. En 1892 fue nombrado arzobispo de Valencia y dos años más tarde promovido a cardenal. En marzo de 1898 fue trasladado a Toledo donde permanecería hasta su muerte. Cfr. A. ORIVE, «Sancha y Hervas, Ciriaco María», en DHEE, vol. IV, pp. 2166-2167.

Últimamente, sobre el importante papel jugado por el cardenal Sancha en la Restauración, la tesis doctoral de C. M. GARCía NiETo, El cardenal Sancha y la unidad de los católicos españoles. Roma, 2005.

13567190 Jacobini-Rampolla, 21 junio 1886. ASV NM 533, Tít. V, Rub. I, Sez. I 17, f. 366.

136 Era la respuesta que Alonso Martínez daba al republicano Azcárate, cuando éste le pregunto sobre las negociaciones del Estado con la Iglesia sobre el matrimonio civil. DSC, 68 (10 marzo 1888), 1745 .

137454 Rampolla-Jacobini, 12 febrero 1886. ASV NM 533, Tít. V, Rub. I, Sez. III 1C, f. 765-766.

138477 Rampolla-Jacobini. Minuta, 17 abril 1886. ASV NM 534, Tít. V, Rub. II, Sez. III 19, ff. 558-559. 
al mismo tiempo, un motivo de desilusión para integristas y republicanos, que esperaban que el alumbramiento de una niña hubiese favorecido sus proyectos.

Sin embargo, el peligro de inestabilidad política permanecía. Por una parte estaba la inestabilidad interna de los dos partidos del turno; por otra, los posibles intentos golpistas de los zorrillistas, que bien administrados por los carlistas les podrían dar opción a una nueva guerra.

Los comentarios que esos días recibía el nuncio no prometían un futuro esperanzador. Había quienes creían, entre ellos el embajador de Austria y Linares Rivas, uno de los jefes de la Izquierda Dinástica, que el matrimonio entre la princesa de Asturias y el hijo del pretendiente carlista hubiera sido más favorable para la monarquía borbónica y para España. Ahora la regencia se tendría que mantener hasta la mayoría de edad del rey, y éste asumir el trono sin experiencia de gobierno, delicado de salud, y sin el apoyo unánime de los monárquicos. Además había que añadir la ambición política de muchos y un ejército proclive a los pronunciamientos.

Canovas, por su parte, estaba dispuesto a hacer todo lo posible por sostener la regencia. Con este fin había puesto todos los medios para que la reina Isabel II permaneciese alejada de la Corte. Había intentado allanar el camino de la reconciliación atrayendo a una parte del carlismo a sus filas. Un plan que no había dado los frutos esperados. Sin embargo, consiguió una buena inteligencia con Sagasta. El jefe conservador había prometido su apoyo a los liberales siempre y cuando estos no amenazasen la legalidad.

En opinión de Rampolla, el partido liberal estaba en una posición fuerte para impedir los desórdenes públicos y evitar posibles alzamientos militares. Sagasta tenía una gran esperanza en el futuro. Uno de los motivos de este optimismo estaba en la actitud de los obispos y del clero, favorable a la regencia. Esto había sido motivo de satisfacción tanto para la Regente como para el gobierno después de años de agitación e indisciplina.

Además la propia Regente se había ganado el favor del pueblo y algunos de los jefes antidinásticos habían reconocido que la República tardaría años en llegar. La buena disposición de los españoles ante la Regente estaba motivada por los deseos de paz y tranquilidad, y por el temor a nuevas guerras.

Ahora bien, el peligro mayor que podía atacar el sistema monárquico era las divisiones internas de los dos partidos del turno, que favorecían a los anticonstitucionales. Por eso el mayor empeño de Cánovas y Sagasta estaba en eliminar a los partidos monárquicos intermedios; de esta forma podrían conseguir que carlistas y republicanos se incorporasen a la lucha legal. En una Cámara dominada por conservadores y liberales, los antidinásticos no tendrían fuerza alguna.

Así las cosas, el problema más importante que el gobierno Sagasta tendría que afrontar era el debate sobre el discurso de la Corona. La Izquierda Dinásti-

Hispania Sacra, Legalidad y conflictos, 58

117, enero-junio 2006, 171-222, ISSN: 0018-215-X 
ca exigiría al gobierno cumplir las reformas prometidas, algunas de ellas de carácter radical. La alternativa que se le plantearía entonces a Sagasta era cumplir el programa radical y perder el apoyo del partido conservador, conviertiendo al aliado en enemigo político; o bien, optar por una política moderada y sufrir la ruptura del sector demócrata de su partido.

La opción más segura, según el propio presidente manifestó al nuncio, retrasar todo lo posible la reforma política y proponer en un año un conjunto de leyes destinas a frenar el avance del socialismo.

En política internacional, la regencia contaba con el favor de la Santa Sede. El agradecimiento por el apoyo recibido obligaba al gobierno español a ponerse del lado del Papa «in tutte le questioni di ordine interno ed internazionale» ${ }^{139}$. Ahora bien, España buscaba además el apoyo de las tres naciones monárquicas europeas, Alemania, Austria y Rusia, con quienes había establecido acuerdos secretos ${ }^{140}$. Respecto a Francia, según informó Moret al nuncio, la restauración

139 Fue una política de conciliación y aceptación del poder constituido. Política que siguió los mismos pasos en España y en Francia. En el primero sosteniendo la regencia de María Cristina; en el segundo, pidiendo a los católicos franceses que aceptasen la III República. Cfr. C. RoBLES MuÑOZ, Insurrección o legalidad. Los católicos y la Restauración, pp. 381-406; ID., "Católicos y libertades políticas (1894). Un año decisivo», Anthologica Anпиa, 42 (1994), 253-277. Siguiendo los trabajos anteriores, he podido estudiar la relación entre León XIII y España en: Aceptar el poder constituido. Los católicos españoles y la Santa Sede en la Restauración (1890-1914), Madrid, 2006.

140 Tras la muerte de Alfonso XII, el gobierno liberal quiso demostrar que su política internacional era la más acertada. Puso en práctica lo que denominó política de ejecución, una vinculación circunstancial de España a la política de la Triple Alianza.

Semanas antes del informe de Rampolla, el 4 de mayo de 1887, España firmaba el Pacto secreto con Italia, al que se adhirieron Alemania y Austria, y del que se informó a Inglaterra. El acuerdo fue renovado en 1891 y finalizó en 1895. En este informe, Rampolla silenciaba el Pacto secreto, bien por desconocimiento, bien por estrategia. Más tarde, la elección de Rampolla como Secretario de Estado evidenciaría la política de aislamiento de León XIII con Italia. Cfr. C. CRISPOLTI-G. AureLI, La politica di Leone XIII da Luigi Galimberti a Mariano Rampolla, Roma, 1912, pp. 280-304.

El proyecto de vincular España a la Triple Alianza fue ideado por Moret. En la Memoria sobre política internacional, elaborada por el propio Moret en noviembre de 1888 y enviado a la Regente, ponía en el punto de mira de la política internacional a las potencias monárquicas europeas, con el fin de dar estabilidad a la monarquía: «España ha de gravitar forzosa y necesariamente hacia la gran alianza monárquica que es hoy la salvaguardia y la garantía de ese principio»: Cit. en F. GARCÍA SANZ, «El Mediterraneo», M. EsPADAS BURGOS (coord.), La época de la Restauración (1875-1902), vol. I: «Estado, Política e Islas de Ultramar», en J. M. ${ }^{a}$ Jover ZAMORA (dir.), Historia de España Menéndez Pidal, Madrid, 2000, p. 664.

En torno a la política internacional de España, la hegemonía del Mediterraneo y el Pacto secreto con Italia: Cfr. F. CuRATo, La questione marocchina e gli accordi mediterranei italo-spagnuoli del 1887 e del 1891. Volume primo: Sino a la caduta del ministro Moret, Milano 1961. Volume secondo: Dal giugno 1888 all'agosto 1896, Milano, 1964. Y los trabajos de C. Robles MuÑoz, «Entre Francia e Italia. El acuerdo verbal hispano-italiano de 1895», Hispania, 192 (1996), 291-322; «El Mediterráneo y la diplomacia secreta. España e Italia en 1894», Rassegna Storica del Risorgimento, 84 (1997), $487-$ 528; «España y el equilibrio en el Mediterráneo (1890-1891)», Hispania, 208 (2001), 583-618; «Il confronto europeo en el Mediterraneo occidentale», Rivista Storica Italiana, 112 (2000), 703-741. 
de la monarquía en el país galo favorecería la paz en España, ya que era en Francia donde se preparaban las conjuras carlistas y republicanas. Ahora bien, lo oposición del canciller Bismarck a la dinastía orleanista, obligaría al gobierno español a favorecer las pretensiones bonapartistas ${ }^{141}$.

\subsection{Los proyectos liberales}

Una semana antes del nacimiento de Alfonso XIII, Sagasta en nombre de la Reina leyó el discurso de la Corona con las líneas principales de su gobierno. Como era de esperar, éste destacó por los principios liberales y una interpretación más amplía de los derechos y libertades que la Constitución de 1876 daba a los españoles. La política liberal de Sagasta tendería hacia una serie de proyectos destinados a garantizar los derechos individuales, como por ejemplo el sufragio universal, el juicio por jurados, la libertad de conciencia y la libertad religiosa ${ }^{142}$.

La Regente hizo una llamada al consenso entre los distintos grupos políticos. Las reformas que pensaban llevar a cabo sólo se podrían realizar si estaba garantizada la paz pública y las pasiones partidistas dejaban espacio al debate. Una vez asegurados los derechos y libertades de la nación, era el momento de entrar en el debate de las ideas. El amplio margen que las sociedades modernas daban a todas las aspiraciones políticas permitía que todos pudieran aspirar al logro de sus ideales en concordia y paz. Fuera de estos dos principios, cualquier reforma seria ineficaz ${ }^{143}$.

Hubo también palabras de agradecimiento hacia León XIII. Hizo mención de la mediación del Papa en el conflicto sobre Las Carolinas ${ }^{144}$. Fue Moret

141 «Il Signor Moret mi ha parlato infine del grande interesse che ha la Spagna per la ristaurazione della Monarchia nella Nazione limitrofa, le cui frontiere sono al presente il gran focolare della cospirazioine, ma sventuratamente scorge la cosa oltremodo difficile per la opposizione decisa del Principe di Bismarck alla monarchia Orleanista. Minore, a suo avviso sarebbe la difficoltá ove si trattasse di portare sul trono di Francia il Principe Vittore Bonaparte, non occultandomi che tale soluzione sarebbe piu conveniente e gradita alla Spagna, la quale teme la influenza sinistra che eserciterebbero i legittimisti francesi, legati intimamente al Carlismo, sul Conte di Parigi»: 501 Rampolla-Jacobini, 28 mayo 1886. ASV SS 249 (1886), 2, ff. 152-160.

Sobre la relación entre España y la política de Bismarck: C. IBÁÑEZ DE IBERo (MARQuÉs DE MuLHACÉN), Los acuerdos secretos de 1887 entre España e Italia. ¿Formó parte España de la Tríplice?, Madrid, 1947; J. SAlom Costa, La política exterior de Cánovas (1875-1881), Madrid, 1967; M. EsPADAS BURGOS, «Alemania y España: de la época bismarckiana a la Gran Guerra», en W. L. BERNECKER (ed.), España y Alemania en la Edad Contemporánea, Frankfurt am Main, 1992, pp. 63-87.

142 DSS, 1 (10 mayo 1886), 2-4.

143 DSS, 2 (10 mayo 1886), 8-10.

144 La documentación diplomática sobre este conflicto se puede ver en Documentos parlamentarios preparados para ser presentados a las Cortes en la legislatura de 1885. Jolo y Bormeo, Madrid,

Hispania Sacra, Legalidad y conflictos, 58

117, enero-junio 2006, 171-222, ISSN: 0018-215-X 
quien redactó la alusión al Papa. En una entrevista con el nuncio, el ministro de Estado agradeció el comportamiento de los obispos y del clero con relación a la actual Monarquía. En la opinión pública se había producido un cambio en la visión que hasta el momento se tenía de la Iglesia. Los partidos políticos tenían ahora la obligación de que esta relación se mantuviese de forma amistosa y al margen de los cambios políticos. Rampolla pidió al gobierno que no levantara cuestiones delicadas que creasen conflictos, que pudieran ser fatales en las circunstancias políticas de la nación. Sagasta había asegurado — señaló Moretque por parte del gobierno esta buena relación no se pondría en peligro ${ }^{145}$.

En la respuesta al mensaje, Sagasta situó su propuesta política entre la reacción progresista y el inmovilismo. Negó que entre Cánovas y él hubiera un pacto. No hubo tal acuerdo, sino que se había buscado el cumplimiento de la ley, la cual exigía que, tras la muerte del Rey, dimitiera el gobierno. Ahora la misión del partido liberal consistía «en facilitar el ejercicio de todas las libertades y de todos los derechos a la sombra de la paz pública, sin la cual e[ra] imposible la práctica de la libertad» ${ }^{146}$.

En el debate, el republicano Azcárate puso en evidencia la difícil situación en la que se encontraba el partido liberal. Tenían que satisfacer dos demandas incompatibles. Ser fieles a su programa y hallar una base común con los conservadores. Si no seguía el programa propuesto cuando estaba en la oposición, tendría las protestas de los republicanos. En cambio, si era fiel a las propuestas liberales no tendría apoyo del partido conservador. Como solución habían optado unos por la parsimonia en llevar adelante el programa fusionista; el partido de la oposición, por el silencio. Era el pacto, que algunos llamaban de El Pardo ${ }^{147}$.

El gobierno, dijo Sagasta, no temía ni los peligros de la derecha ni los de la izquierda. Estaba seguro que unos y otros actuarían de forma patriótica y respetarían las leyes. La política fusionista no daría motivos ni a unos ni a otros ${ }^{148}$. Los liberales defendían la legalidad que había sido obra de la voluntad na-

1886; Documentos diplomáticos presentados a las Cortes en la legislatura de 1887 por el Ministerio de Estado, Madrid, 1887. Las noticias sobre la mediación de León XIII en ASV NM 523, Tít. II, Rub. I, Sez. I 21, ff. 741r-743v; 534, Tít. V, Rub. II, Sez. III 18, ff. 509r-536v. Cfr. C. Robles MuÑOz, «El protocolo hispano-alemán de 1885 sobre Las Carolinas y Las Palaos. El arbitraje de León XIII», Missionalia Hispanica, 43 (1986), 101-141.

145497 Rampolla-Jacobini, 20 mayo 1886. ASV SS 249 (1886), 2, ff. 148-149.

146 DSS, 19 (31 mayo 1886), 183-187.

147 «... un contrato, un pacto implícito entre ambos partidos porque sienten la necesidad de no separarse de una manera radical, que llevaría consigo la ruina de lo que ambos quieren sostener...»: DSC, 37 (23 junio 1886) 623-627. No fue, sin embargo, en el palacio de El Pardo donde se llegó al acuerdo entre Cánovas y Sagasta, sino en la sede de la Presidencia del Consejo, en Madrid. Cfr. A. LARIO, El Rey, piloto sin brújula. La Corona y el sistema político de la Restauración (1875-1902), pp. 202-208.

${ }^{148}$ DSC, 39 (26 junio 1886), 689-691. 
cional. Una legalidad que se fundamentaba en la Constitución de 1876, donde se afirmaba que la soberanía nacional estaba representada por las Cortes y el Rey. Esto significaba que la Restauración era continuadora de la política septembrina; no había cortado los hilos de la historia nacional. Y esta continuidad la habían seguido primero los conservadores y ahora tocaba a los liberales ${ }^{149}$.

\subsubsection{La reforma del Código Penal}

Una de las primeras medidas adoptadas por el nuevo gobierno fue la reforma del Código Penal. Coincidiendo con los debates en el Senado se producirían nuevos ataques de la prensa liberal contra la Iglesia. La razón estaba en la aprobación por parte de la Congregación del Índice de la obra del sacerdote catalán Sardá y Salvany, El liberalismo es pecado. Rampolla pidió a Alonso Martínez que pusiera freno a los periódicos que atacaban los intereses de la religión. El ministro aludió a las leyes de libertad de prensa aprobadas en la época del Sexenio y difíciles derogar. Prometió que en la revisión que se hiciera del Código Penal no faltarían las medidas oportunas. La excusa que le sirvió a Alonso Martínez para poner en marcha su proyecto fueron las diligencias que el ministro de la Guerra presentó contra El Progreso, periódico antidinástico, por propagar la noticia falsa de una sublevación. El periódico apeló a las leyes de libertad de prensa para no ser procesado ${ }^{150}$.

En el Senado presentó una modificación al texto del Código Penal el conservador Cangas-Argüelles. Pidió que se introdujera en la base $6 .^{\text {a151 }}$ una alusión a las publicaciones que atacasen a las creencias religiosas y las leyes de la religión católica. Tales publicaciones cometían un delito contra el artículo 11 de la Constitución ${ }^{152}$. La Comisión del Senado que estudiaba el proyecto de ley de reforma, desestimó la propuesta. Cangas-Argüelles justificó su enmienda afirmando que era la forma de acomodar el Código Penal a la Constitución. Quiso aprovechar la alusión que Alonso Martínez hizo a El Progreso. El mismo periódico había publicado una serie de artículos injuriosos contra la religión católica. Era necesario que la Iglesia fuese tutelada y defendida por el Estado mediante las leyes. Esto se realizaría en la medida en que el gobierno adaptase el nuevo Código al artículo 11 de la Constitución, donde se afirmaba que la religión ca-

\footnotetext{
149 DSC, 37 (23 junio 1886), 627-635.

150576 Rampolla-Jacobini, 22 febrero 1887. ASV SS 249 (1887), 2, ff. 46r-48r.

151 «Se llenarán los vacíos que la experiencia haya hecho notar hasta ahora, ya que el castigo de algunos hechos justificables que hoy se encuentran sin sanción penal o sin sanción suficiente, ya para dar más flexibilidad, según los casos, al rigor de las penas señaladas a varios delitos, ya para fijar el verdadero carácter y concepto de algunos, teniendo al efecto en cuenta la misma jurisprudencia del Tribunal Supremo»: DSS, 3 (18 enero 1887), Apéndice trigésimo segundo.

152 DSS, 23 (11 febrero 1887), Apéndice undécimo.

Hispania Sacra, Legalidad y conflictos, 58

117, enero-junio 2006, 171-222, ISSN: 0018-215-X
} 
tólica era la religión del Estado ${ }^{153}$. Apoyó la modificación el obispo de Zamora. Era deber del gobierno hacer desaparecer aquellas enseñanzas contrarias a la doctrina de Jesucristo ${ }^{154}$.

Alonso Martínez afirmó estar de acuerdo con el fondo de la cuestión. Los pueblos religiosos eran los más libres. El ateismo y la obscenidad no eran conquistas de la civilización moderna. Además el gobierno tenía una deuda con la Iglesia; la actitud de los obispos ante la muerte del Rey y el apoyo a la Regente habían servido al mantenimiento de la paz. No había, por tanto, inconveniente en que una base impusiera sanciones penales para proteger el culto y sus ministros, las ceremonias y las manifestaciones públicas de la religión católica, sin que esto fuera en perjuicio de la tolerancia religiosa ${ }^{155}$.

\subsubsection{La ley de asociaciones}

A principios de marzo cambió el gobierno. Salió el general Ignacio del Castillo, ministro de la Guerra. El malcontento en el ejército estaba provocando tensiones. Sagasta pensó que había que procurar tranquilizar los ánimos y evitar nuevos levantamientos militares. Entró el general Manuel Cassola, liberal-fusionista, que había sido diputado durante ocho años. Era conocido como militar pero no como político. Sagasta consiguió rebajar tensión entre los militares, pero no en el gobierno. El sector más demócrata, formado por Moret, Balaguer y López Puigcerver, estaba descontento ya que se perdía el equilibrio entre los distintos grupos liberales del gobierno ${ }^{156}$.

La crisis no impidió que el gobierno siguiera adelante con su política. Otro de los proyectos del partido liberal fue ampliar los derechos de asociación de los ciudadanos. Para ello Venancio González, ministro de Gobernación, presentó un nuevo proyecto de ley de asociaciones ${ }^{157}$, que se debatiría en la legislatura siguiente. Fernández Villaverde, en nombre del partido conservador, advirtió de los graves peligros que la aprobación de esa ley traería. Los conservadores veían en el proyecto una vuelta a la legislación de 1869. Su aprobación significaba desarmar al Estado y debilitar su facultad para suspender las asociaciones. Había que tener en cuenta el peligro que en toda Europa suponía el socialismo y en España era necesario precaverse de los intentos repu-

153 DSS, 26 (15 febrero 1887), 568-575.

154 «Si el mal consiste en enseñanzas contrarias a las de Jesucristo, deber nuestro es hacerlas desaparecer, combatirlas por medio de artículos precisos, concretos que se pongan en el Código»: DSS, 26 (15 febrero 1887), 575-576.

155 DSS, 26 (15 febrero 1887), 578-579.

156579 Rampolla-Jacobini, 9 marzo 1887. ASV SS 249 (1887), 2, ff. 44-45.

157 DSC, 51 (12 julio 1886), 999. 
blicanos. El gobierno, en cambio, por medio de esta ley, les allanaba el camino ${ }^{158}$.

Para el gobierno la ley significaba un paso más en el conjunto de libertades y derechos aprobados durante la presidencia de Cánovas. Las leyes eran solidarias. Si en un país donde había un cierto número de libertades una se mutilaba, todo el equilibrio de las fuerzas sociales sufría las consecuencias. Impedir una ley de asociación daba lugar a ciertos peligros. Era la Constitución la que recogía este derecho, que debían regular las leyes ${ }^{159}$.

El proyecto se debatió con rapidez. El 17 de marzo era aprobado en el Congreso y remitido para su discusión y aprobación en el Senado ${ }^{160}$. La Comisión encargada de discutirlo y presentarlo a su aprobación introdujo una enmienda al artículo tercero, según el cual se excluían de las disposiciones de esta ley los institutos religiosos que se contemplaban en el artículo 29 del Concordato de $1851^{161}$.

En el debate, los conservadores volvieron sobre las mismas acusaciones vertidas en el Congreso. La ley significaba el retorno del espíritu democrático de la Constitución de 1869 que pretendían introducirlo en la de $1876^{162}$. Respecto a las órdenes religiosas, Cangas-Argüelles propuso incorporar no sólo aquellas que estaban en el Concordato, sino además todas las asociaciones católicas aprobadas por la Santa Sede y admitidas en España ${ }^{163}$. El debate se centró sobre la interpretación de los artículos 13 y 14 de la Constitución y en la amplitud que se quería dar al término «libremente» que aparecía en dichos artículos. Las asociaciones religiosas estaban fuera de este debate. Por pertenecer y tener un fin religioso estaban por encima de las condiciones del derecho común ${ }^{164}$.

\footnotetext{
158 DSC, 37 (4 marzo 1887), 936-944.

159 DSC, 37 (4 marzo 1887), 944-949.

160 DSS, 49 (18 marzo 1887), Apéndice primero.

161 «Art. 3. ${ }^{\circ}$ Se exceptúan de las disposiciones de la presente ley: $1 .^{\circ}$ Los institutos de la religión
} católica a que se refieren el Art. 29 del Concordato de 1851, los cuales se regirán por los preceptos canónicos vigentes en España y por las leyes del Reino que regulan la materia»: DSS, 64 (6 abril 1887), Apéndice primero.

Eran tres las órdenes citadas en el Concordato: la de San Vicente de Paul, San Felipe Neri y una tercera sin concretar. Cfr. A. MERCATI (a cura di), Raccolta di Concordati su materie ecclesiastiche tra la Santa Sede e la Autorità Civili, vol. I: 1098-1914, Città del Vaticano, 1954, p. 786.

162 DSS, 65 (11 abril 1887), 1395-1400.

163 DSS, 66 (12 abril 1887), 1416-1423. La enmienda presentada por Cangas-Argüelles a la Comisión del Senado: DSS, 65 (11 abril 1887), Apéndice primero: «El art. 3. ${ }^{\circ}$, párrafo $1 .^{\circ}$ del dictamen de la Comisión, será sustituido por el artículo 16 del proyecto aprobado y remitido por el Congreso de los Diputados, que dice así: También se exceptúan de esta ley las asociaciones de la Religión católica autorizadas en España por el Concordato. Las demás asociaciones religiosas se regirán por esta ley, aunque debiendo acomodarse en sus actos las no católicas a los límites señalados por el artículo 11 de la Constitución del Estado».

164 DSS, 67 (13 abril 1887), 1435-1449.

Hispania Sacra, Legalidad y conflictos, 58

117, enero-junio 2006, 171-222, ISSN: 0018-215-X 
Al final hubo consenso entre liberales y conservadores. Las necesidades del país hicieron que ambos grupos políticos se uniesen y elaborasen una obra de concordia y de tregua. Ninguno de los dos estaba dispuesto a romperla. La Constitución tenía suficiente elasticidad para que conservadores y liberales pudiesen gobernar con ella. Respecto a las órdenes religiosas había que tener en cuenta que legislar sobre las aprobadas por el Papa era entrar en materia concordada, y aquí la Iglesia tenía su propia autoridad ${ }^{165}$.

El 25 de abril era remitido al Congreso ${ }^{166}$ y se formaba la comisión mixta que debía discutir las enmiendas presentadas por el Senado. Entre otros, la formaron Alfonso González, Andrés Mellado y José Canalejas, que fue su presidente $^{167}$. El dictamen de la Comisión aprobó las enmiendas propuestas e incorporó el artículo referido a las asociaciones religiosas, pero como artículo segundo. Así sería presentado a las Cortes que lo aprobaba el 21 de mayo. Dos días más tarde lo remitía a la Regente para su firma ${ }^{168}$.

\subsubsection{La llegada de un nuevo nuncio y la crisis del gobierno Sagasta}

Los debates en el Senado, donde estaban representados los obispos, y la ausencia de notas entre el gobierno y la Santa Sede, demostraban que la ley de asociaciones pasó desapercibida y no se vio en ella un motivo para romper la concordia y armonía conseguida hasta el momento. Las relaciones entre el gobierno Sagasta y la Iglesia, especialmente con el episcopado, habían ganado en fluidez. Todo ello había sido obra del nuncio. Como era tradición, el agradecimiento de la Regente a Rampolla se hizo público cuando éste fue nombrado cardenal $^{169}$. La Reina le hizo entrega de la birreta cardenalicia en un acto que tuvo lugar en la Capilla real, con la presencia de todo el gobierno y el Cuerpo Diplomático acreditado en España ${ }^{170}$. Un mes más tarde, Mario Mocenni, Sustituto de la Secretaria de Estado, comunicaba a Rampolla el nombramiento de Di Pietro como nuevo nuncio en España ${ }^{171}$.

A principios de junio de ese año, Léon XIII lo nombraba Secretario de Estado en sustitución del difunto Jacobini ${ }^{172}$. En la circular de despedida a los obis-

165 DSS, 71 (18 abril 1887), 1531-1545.

166 DSC, 76 (25 abril 1887), Apéndice tercero.

167 DSS, 79 (27 abril 1887), 1695. El nombramiento de Canalejas como Presidente de la Comisión mixta: DSS, 92 (14 mayo 1887), 1963.

168 DSS, 99 (25 mayo 1887), Apéndice sexto.

169582 Rampolla-Jacobini. Minuta, 26 de marzo de 1887. ASV NM 520, Tít. I, Rub. I, Sez. III [s. n.], f. 364rv.

170582 Rampolla-Jacobini. Minuta, 26 de marzo de 1887. ASV NM 520, Tít. I, Rub. I, Sez. III [s. n.], f. 364.

${ }_{171} 69985$ Moncenni-Rampolla, 21 abril 1887. ASV NM 519, Tít. I, Rub. I, Sez. I 10, f. 196.

172 La prensa española, al dar la noticia de la muerte del Secretario de Estado, anunciaba que los 
pos españoles, Rampolla puso de manifiesto su agradecimiento al episcopado por la cooperación que le había prestado en el ejercicio de sus funciones como nuncio. La adhesión que los obispos hicieron a las enseñanzas del Papa, aseguraba en España la influencia de la religión católica. Apelaba al fraternal afecto con el que estaría siempre unido a la Iglesia española:

\begin{abstract}
«Unido seguiré a él con estrecho vínculo de amor, y en Roma o en donde quiera que la Divina Providencia se digne colocarme, haré gustosísimo cuanto esté de mi parte a favor de España, teniendo una especial satisfacción si me es dado ser en algo útil a sus dignos obispos. La ausencia y la distancia no entibiarán el fraternal afecto que por ellos siento y que a ellos me une y de cuyas virtudes y relevante mérito daré siempre público testimonio...» ${ }^{173}$.
\end{abstract}

El nuevo nuncio, Angelo di Pietro ${ }^{174}$ llegó a Madrid el 30 de junio ${ }^{175}$. Una semana después presentaba sus credenciales a la Reina y enviaba una circular de presentación a los obispos. Manifestaba el gran afecto que León XIII sentía por España, mostrado en distintas ocasiones ${ }^{176}$. Los obispos habían manifestado su adhesión al Papa siguiendo indicaciones. Rampolla las había puesto en práctica trabajando por la unidad y la concordia en el episcopado y entre los católicos. La próxima celebración del Jubileo sacerdotal de León XIII sería un momento propicio para mostrar una vez más las pruebas de unión con el Papa ${ }^{177}$.

En las instrucciones que el Secretario de Estado daba a Di Pietro ${ }^{178}$, se hacía balance de los acontecimientos sucedidos desde la Restauración. En relación

\footnotetext{
dos candidatos posibles eran Rampolla y Di Pietro. «Muerte del Cardenal Jacobini», El Imparcial (7 marzo 1887), 1.

173 Rampolla-Obispos, 26 abril 1887. ASV NM 519, Tít. I, Rub. I, Sez. I 10, f. 164.

174 Angelo di Pietro (1828-1914). Ordenado sacerdote el 20 de diciembre de 1851. Doctor en Derecho, fue Secretario y Provicario de la diócesis Tiburtina y después Vicario General de la diócesis de Ostia. El 1 de julio de 1866 fue consagrado obispo auxiliar de la diócesis de Ostia-Veliternese. Comienza su carrera diplomática como Delegado Apostólico en Paraguay, Uruguay y Argentina. El 30 de septiembre de 1879 es nombrado nuncio en Brasil y tres años más tarde en Baviera. El 16 de mayo de 1887 León XIII lo nombraba nuncio en España. Cfr. R. RITZLER-P. SEFrin, Hierarchia Catholica Medii et Recenctioris Aevi, vol. VIII, p. 36.

1751 Di Pietro-Rampolla, 1 julio 1887. ASV SS 249 (1887), 3, f. 38.

176 El nombramiento del nuevo nuncio en España había estado entre Di Pietro y Galimberti. El Papa finalmente se decidió por Di Pietro y envió a Galimberti a Viena. El embajador español manifestó la satisfacción del gobierno. Esperaba que el nuevo nuncio siguiera los pasos de Rampolla. Con este fin, según manifestó León XIII al embajador español, el Papa había pedido a Di Pietro que se entrevistara con Rampolla para que aquel continuase la política de su antecesor. 86 Groizard-Ministro Estado, 26 abril 1887 AMAE H 1739.

177 Circular. Di Pietro-Obispos, 7 julio 1887. ASV NM 560, Tít. II, Rub. IV, Sez. II 1, f. 429. Las respuestas de los obispos en las que se daba la bienvenida al nuevo nuncio: ASV NM 560, Tít. II, Rub. IV, Sez. II 1, ff. 431-531.

${ }^{178}$ Istruzioni per Monsgr. Angelo Di Pietro, Arcivescovo, Tít.. di Nazianzo, nuncio Apostolico in Spagna, 18 julio 1887. ASV NM 560, Tít. I, Rub. I, Sez. IV. Vid. F. DíAZ DE CERIO-M. F. NúÑEZ Y MuÑoz, Instrucciones decretas a los nuncios de España en el siglo XIX (1847-1907), Roma, 1989, pp. 291-298.
}

Hispania Sacra, Legalidad y conflictos, 58

117, enero-junio 2006, 171-222, ISSN: 0018-215-X 
con la Iglesia, la monarquía de Alfonso XII había resarcido de la persecución sufrida durante el Sexenio revolucionario. Sin embargo, la Constitución de 1876, sobre una base liberal, había quitado la unidad católica, introduciendo el principio de tolerancia religiosa.

Tras la muerte del Rey, el gobierno liberal de Sagasta había conseguido evitar cualquier tipo de sublevación. La misma actuación de la Iglesia en estos momentos fue muy bien vista por la Monarquía y por todos los partidos. Pero esto no consiguió acabar con la división existente entre los católicos. Estos formaban tres grupos principales: carlistas, integristas y alfonsinos. Por eso al comienzo de la regencia, se buscó apartar a obispos y clero de las luchas políticas siguiendo la dirección marcada por las enseñanzas pontificias. Esta actuación de la Santa Sede y de los obispos había permitido mejorar mucho la situación, debido principalmente a la abstención del clero en las cuestiones políticas y la actuación del Vaticano recordando los deberes de los periodistas católicos, denunciando los abusos de la prensa integrista. Cuando Pidal entró en el gobierno conservador desapareció la Unión Católica ${ }^{179}$, que había provocado los ataques de los carlistas contra la autoridad episcopal. Faltos de prestigio, unos y otros, demostraron tener como primer interés las ambiciones personales y la defensa de las ideas políticas, valiéndose de la causa católica.

Se había conseguido mantener unido al episcopado para lograr la pacificación. Ahora el nuncio debía evitar en todo momento tomar partido, para no dejarse convertir en un instrumento de las ambiciones políticas. Al mismo tiempo su acción debía dirigirse a evitar que el clero, secular y regular, se implicase en las contiendas políticas de los periódicos y revistas de marcado carácter político. Para ello tenía la encíclica Cum multa de León XIII y la circular que desde la nunciatura se envió a los obispos el 9 de julio de $1883^{180}$. En cuanto a las disputas que se podían producir sobre la mejor forma de gobierno, estaban las indicaciones dadas en la Immortale Dei.

Había algunas cuestiones a las que el nuncio debía atender de manera especial. Estaban por una parte los intentos de convocar Sínodos Provinciales. Se

179 Sobre la Unión Católica y su incorporación al gobierno conservador: Cfr. M. FERNÁNDEZ ALMAGRO, «Alejandro Pidal y su entrada en el gobierno de Cánovas de 1884», Boletín de la Real Academia de la Historia, 120 (1947), 231-248.

En torno a la disolución de la Unión Católica y la intervención de la Santa Sede: Cfr. C. RoBLES MuÑZ, «La Unión Católica, su significación y su fracaso», Burgense, 28 (1987), 109-168, y la tesis de J. M. a MagaZ, La Unión Católica (1881-1885), Roma, 1990.

180 En torno a la actuación de la Santa Sede en relación a la política española y la división de los católicos: Cfr. V. CÁrCEL ORTí, «León XIII fautor de unidad del catolicismo español. A propósito de la encíclica «Cum multa» (8-XII-1882)», en Studia Historica et Philologica in honorem M. Batllori, Roma, 1984, pp. 123-141; C. RoBles MuÑoZ, «La Cum multa de León XIII y el movimiento católico en España (1882-1884)», Hispania Sacra, 39 (1987), 297-348. 
había conseguido plena libertad para que los obispos pudieran reunirse y era inminente el que se celebraría en Valladolid.

En relación con el Estado se había llegado a un acuerdo sobre la creación de una Universidad católica en España, dependiente sólo de los obispos. Proyecto que se paró por la muerte del rey. Ahora el ministro de Fomento, Montero Ríos había derogado un Real Decreto de Pidal ventajoso para la Iglesia. Pero había una cuestión todavía pendiente y a la cual el nuncio debía prestar mayor atención. Era el proyecto de ley sobre el matrimonio civil que los liberales habían presentado. Se había llegado a un acuerdo satisfactorio para ambas partes, para que en la base tercera del Código Civil — donde se trataba del matrimonioquedase garantizada la celebración del matrimonio canónico para los católicos. Una vez remitido al ministro de Gracia y Justicia, éste lo debía someter a la Comisión que estaba trabajando sobre el Código Civil y presentarlo a las Cortes. El acuerdo verbal de Alonso Martínez con la Santa Sede exigía que éste actuase de mutuo acuerdo en la redacción de estos artículos del Código. El nuncio tenía que preocuparse para que en la Comisión se respetasen las leyes canónicas.

Sobre los Sínodos Provinciales ya había informado Rampolla durante su labor en la nunciatura de Madrid. Se quejaba entonces el nuncio del abandono en que se había tenido la celebración de estos Sínodos. Era el medio más adecuado para mantener la concordia y unidad entre los obispos, y la forma más eficaz de defender los derechos de la Iglesia, evitar abusos que se estaban cometiendo en la disciplina eclesiástica y elevar el estado decadente en el que se encontraba el clero.

Hubo varias causas para que estos no se hubieran celebrado. Por parte de los obispos, además de las divisiones existentes entre ellos, les servía de excusa los motivos de lejanía, los costes del viaje y de la estancia, y la falta de costumbre en la celebración de los Sínodos. Por parte del gobierno perduraba la antigua tradición del exequátur. Además los obispos no podían celebrar reuniones sin el permiso del gobierno y con la intervención de un comisario real. La Santa Sede por su parte había procurado poner todos los medios para que se celebrasen. En 1877, cuando Rampolla era encargado de negocios de la nunciatura, tuvo una entrevista sobre este tema con Silvela, entonces ministro de Estado, y del cual sólo obtuvo una respuesta vaga.

Ahora las circunstancias habían cambiado. El momento que vivía la Iglesia y sus buenas relaciones con el gobierno Sagasta, especialmente por la posición favorable de los obispos a la regencia, permitió que comenzaran a convocarse los Concilios provinciales. En la provincia eclesiástica de Valladolid, donde existían excelentes relaciones entre ellos, los obispos aprovecharon esta situación. Tomás Cámara se entrevistó de forma confidencial con Sagasta y Alonso Martínez. Consiguió del gobierno plena libertad para que los obispos se reunie-

Hispania Sacra, Legalidad y conflictos, 58

117, enero-junio 2006, 171-222, ISSN: 0018-215-X 
ran en Sínodos provinciales. Ante esta oportunidad, Rampolla trató con los arzobispos de Valladolid y Compostela la posibilidad de convocarlos. El primero, de hecho, ya había presentado las materias a discutir con los sufragáneos ${ }^{181}$.

En julio la prensa dio la noticia del comienzo de los Sínodos. Tenían una gran importancia no sólo en el orden religioso, sino también en el político y en el social. No se temía ya que fueran a romper la armonía que existía entre la Iglesia y el Estado ${ }^{182}$. Las reuniones de los obispos en Sínodos servirían - según noticias de la prensa- para mantener la unión entre los católicos y hacerla eficaz. Era el medio adecuado para movilizar a los católicos en defensa de los intereses religiosos. Sin embargo no faltaron las críticas. En el periódico $\mathrm{El} R \boldsymbol{R}$ sumen se acusaba a los obispos de cambiar de política según el Papa que gobernase. Los Concilios provinciales se habían hecho a instancias de la nunciatura y de los obispos reunidos en Madrid por la muerte del Rey ${ }^{183}$. Pero el paso dado en Valladolid y Compostela serviría de ejemplo para otras diócesis como Granada y Zaragoza que se disponían a organizar sus propios Sínodos ${ }^{184}$. Era la ocasión propicia, según El Imparcial, para que la Iglesia española despertara de su letargo y dejara para siempre las influencias ultramontanas que habían matado el espíritu democrático en la Iglesia ${ }^{185}$.

Favoreció también una acción conjunta de los obispos y católicos la carta de León XIII a Rampolla con motivo de su nombramiento como Secretario de Estado. León XIII, en referencia a España, señalaba la necesidad

«... de la unión entre los católicos para la defensa generosa y desinteresada de la Religión, en la adhesión sincera a la Santa Sede y en la caridad recíproca, a fin de que no se dejen arrastrar, ni por móviles personales, ni por el espíritu de partido...» ${ }^{186}$.

Esta orientación que el Papa dio a los católicos comenzaba a dar sus frutos en España, según informaba Di Pietro. Junto a los Sínodos Provinciales, hubo iniciativas para crear periódicos católicos que siguieran las indicaciones dadas por León XIII. Así sucedió con El Diario de Barcelona y lo mismo en Tortosa donde se fundó La Orden, cuyo programa era la unión que quería León XIII.

Así las cosas, la cohesión en el gobierno comenzaba a debilitarse. En el partido liberal había fuertes discrepancias sobre cuestiones importantes, como por

181575 Rampolla-Jacobini, 20 febrero 1887. ASV SS 249 (1887), 2, ff. 40-41.

182 «La Iglesia española», El Imparcial (16 julio 1887), 1.

18324 Di Pietro-Rampolla, 29 agosto 1887. ASV SS 249 (1887), 3, ff. 163-167.

18438 Di Pietro-Rampolla, 30 septiembre 1887. ASV SS 249 (1887), 3, ff. 170-174.

185 «La Iglesia Nacional», El Imparcial (29 agosto 1887), 1-2.

186 LEO PP. XIII, «Lettera "Quantunque Le siano" sugli orientamenti dell' atività pontifiicia», LEONIS XIII P. M., Acta, vol. VII, Romae, 1888, pp. 134-153; trad. española, «Carta de S. S. León XIII al Secretario de Estado», Boletín Eclesiástico del Arzobispado de Burgos, Año XXX, 1 de agosto de 1887, n. $^{\circ} 18$, pp. $229-242$. 
ejemplo la ley de reforma militar. Se acusaba a los liberales de no haber llevado adelante el programa del partido. Otra de las fuertes críticas era la situación de inmoralidad administrativa en la que se encontraba Cuba. Por parte del gobierno hubo intentos de solucionar los abusos que se cometían y comenzar las reformas planteadas cuando estaban en la oposición, pero las censuras de los más radicales crecían. Entre estos se encontraba Cristino Martos, que sin dejar la vinculación con los fusionistas, pretendía empezar él con las reformas exigidas, lo que podría provocar una crisis en el gobierno.

Sagasta quiso reforzar su posición con la unión de los reformistas de López Domínguez y la amnistía a Zorrilla. El encargado de llevar adelante los acuerdos fue Moret que en un discurso pronunciado en Cádiz apeló al patriotismo del general y después lo visitó en San Sebastián. Los más críticos con el gobierno no veían posible esta unión debido a las diferencias que separaba a López Domínguez y a Martínez Campos.

Entre las reformas que el gobierno quería adoptar, se encontraban las de Alonso Martínez y Montero Ríos. Éste había pronunciado un discurso en el Congreso pedagógico a favor de la centralización de la enseñanza primaria, la formación del profesorado, y abogó por la necesidad de una enseñanza religiosa frente a una educación laica, pero salvando siempre la libertad de conciencia, por lo que esta enseñanza no tendría por qué ser la católica. Alonso Martínez, por su parte, pretendía introducir reformas en la Magistratura, el matrimonio civil, el Código Penal y la ley electoral ${ }^{187}$.

Había además entre los mismos ministros discrepancias irresolubles. Entre Moret y León y Castillo no había inteligencia. El ministro de la Guerra, General Cassola, no estaba dispuesto a transigir con su proyecto de reforma militar, y Balaguer, ministro de Ultramar, estaba resentido con el general Salamanca.

Las luchas entre las distintas facciones del partido liberal se trasladaron a la prensa, donde los periódicos de unos y otros se lanzaban ataques. A pesar de todo, algunos esperaban que el ministerio se pudiese mantener durante un tiempo. Las razones aducidas eran las divisiones existentes también en otros partidos y porque sería la forma de garantizar el orden público. Además el partido conservador, en caso de llegar al poder, hubiera tenido que soportar una fuerte presión de los republicanos ${ }^{188}$.

Los conservadores, por su parte, no tenían prisa por llegar al poder. La política del gobierno no les incomodaba por el momento. Pero Cánovas estaría dispuesto a aceptarlo, sobre todo para evitar que siguiera la disidencia de aquellos que deseaban llegar al poder y en protesta se pasaban al partido de Romero Ro-

18724 Di Pietro-Rampolla, 29 agosto 1887. ASV SS 249 (1887), 3, ff. 163-167.

18838 Di Pietro-Rampolla, 30 septiembre 1887. ASV SS 249 (1887), 3, ff. 170-174.

Hispania Sacra, Legalidad y conflictos, 58

117, enero-junio 2006, 171-222, ISSN: 0018-215-X 
bledo. A pesar de esto los romeristas no mostraban excesiva vitalidad y se anunciaba una posible crisis en el partido, especialmente si Moret y Martos conseguían separar a López Domínguez. Pero mientras Sagasta permaneciera en el poder, Cánovas lo respetaría según acordaron tras la muerte del rey Alfonso XII.

En los partidos antidinásticos los republicanos tenían fuertes luchas intestinas que habían llevado a la ruptura total entre los partidarios de Pí y los de Zorrilla. Podía ser una táctica, según comentarios de periódicos, pero no parecía probable una nueva reorganización republicana. Castelar por su parte lanzaba duras críticas contra los demás partidos republicanos, haciendo de su postura un ejemplo de verdadero republicanismo ${ }^{189}$.

Sin embargo, la visita que la Reina realizó a las provincias del norte durante el verano, consiguió una trasformación en los planteamientos tradicionalistas. Según la prensa, el viaje fue organizado por el marqués de Pidal. Sagasta no habría ido porque al ser gran oriente tenía miedo de que los jesuitas no lo recibieran bien ${ }^{190}$.

Moret informó de todo esto a Rampolla ${ }^{191}$. El viaje sirvió para reafirmar la popularidad de la Reina entre la población, que veía en ella el ideal de la mujer cristiana. El reconocimiento que la Monarquía había tenido en el pueblo, después de la muerte del Rey, se debía principalmente a la sencillez y costumbres de la Reina y a la forma en la que se había presentado a toda la nación, como una madre encargada de conservar el Trono para su hijo.

La visita tuvo un efecto inmediato entre las filas carlistas. Hizo que estos perdieran la cohesión de partido y que un sector del mismo comenzara a ver en la Reina la Monarquía que representaba. D. Carlos intentó detener la división que se producía en sus filas. El gobierno francés permitió al duque de Madrid cruzar la frontera italiana y permanecer tres días en Burdeos, a pesar de que el gobierno no quería mostrar ninguna deferencia hacia D. Carlos por sus pretensiones al Trono español.

Allí reunió a sus consejeros para confirmar las antiguas disposiciones y alentar a los más vacilantes. Triunfó el sector más intransigente frente a los que postulaban una reconciliación. Tenían preparados planes para una sublevación, promovida principalmente por carlistas residentes en Italia. Pero ante la vigilancia del gobierno no prosperó. Pero los republicanos intentaron aprovechar la situación para hacer triunfar su causa. Según Moret, la situación actual hacía conveniente un nuevo mensaje del Papa en el que éste mostrara su apoyo a la regencia, como ya había hecho en otras ocasiones.

18938 Di Pietro-Rampolla, 30 septiembre 1887. ASV SS 249 (1887), 3, ff. 170-174.

190 «Adular el carlismo», El Liberal (24 septiembre 1887), 1-2.

191 Moret-Rampolla, s. f. ASV SS 249 (1888), 2, ff. 101-107. 
Otro de los incidentes del viaje que convenía aclarar, según Moret, fue la visita que la Reina hizo a Loyola. La prensa liberal afirmó que la Regente fue recibida en Azpeítia de una manera muy fría. Censuraron que los ministros hubiesen aconsejado a la Reina la visita a Loyola, cuna del carlismo ${ }^{192}$. No fue así. Según El Imparcial, la Regente fue recibida en Azpeítia por la banda municipal, dirigida por un carlista, que a su paso tocó la marcha real. Tampoco hubo frialdad por parte de los jesuitas de Loyola. La recibieron en la puerta del Santuario el nuevo rector junto con el antiguo, y la acompañaron durante toda la visita ${ }^{193}$. Esta versión la confirmó Moret a Rampolla, «los jesuitas se condujeron de la manera más correcta y no sólo no hubo de su parte falta ni aun omisión, sino que después de cumplir a satisfacción sus deberes de cortesía, mostraron de una manera que no dejó lugar a dudas, sentimientos de respeto, de simpatía y aun pudiera decirse de afecto a la Reina y a sus hijas».

En la visita a Pamplona, según relataron Sagasta y Cassola, que acompañaban a la Reina, estuvo presente un sector del clero, conocido por su pertenencia al partido carlista. Su conducta fue digna de todo elogio. Esto no hubiera sido así si los carlistas de Loyola hubiesen actuado de otra forma.

Por último, Moret analizó la situación política. Aseguró en primer lugar que el gobierno no se había apartado de la política seguida desde el primer momento y que, como había dicho a Rampolla, siendo este nuncio, garantizaban la paz y la concordia con la Iglesia. En cambio, continuaba la división entre los republicanos, cada día más debilitados. Los carlistas estaban intentando ridiculizar los buenos efectos de la visita de la Reina. De no lograrlo, eso significaría que los enemigos de la legalidad habrían perdido terreno, justo cuando pensaban que la situación les favorecía.

En política exterior habló Moret de la cuestión de Marruecos. El Sultán había pedido una nueva reunión de la Conferencia de Madrid con el fin de modificar el derecho de protección. Esto obligaría a las potencias europeas a definir su política en el Mediterráneo. Estaba en conversaciones con los gobiernos europeos para que se pudiera convocar en Madrid una nueva Conferencia europea, lo que afianzaría la política española en Marruecos. Mientras, el gobierno estaba sufriendo un fuerte desgaste, pero por el momento no peligraba la Presidencia ni era viable el regreso de los conservadores al poder.

Las desavenencias producidas entre los liberales fueron resueltas cuando los liberales que discrepaban con la política gubernamental, Gullón, Martos, Vega de Armijo, manifestaron públicamente su adhesión al gobierno. La razón de este cambio estaba en que Sagasta empezaría en breve reformas de carácter liberal que agradaban a los más radicales. Al mismo tiempo reaccionaban los

\footnotetext{
192 «Adular el carlismo», El Liberal (24 septiembre 1887), 1-2.

193 El Imparcial (24 septiembre 1887), 1.
} 
partidos de la oposición. Los reformistas rechazaban la entrada en el partido fusionista. Eran un partido fuerte y vital con posibilidades de hacer frente tanto a conservadores como a fusionistas. Esto no significaría un ataque a la legalidad, su lema «Patria, Libertad y Monarquía», era garantía de la fe que ponían en el sistema restauracionista, pero saldrían de él si no se les tenía en cuenta a la hora de formar gobierno.

Cánovas, en la reunión del partido conservador el 23 de octubre, dijo que no se unirían en la oposición al gobierno con aquellos que amenazaban con poner en peligro las instituciones. Combatiría los proyectos gubernamentales que creyese peligrosos para el país, pero los sostendría cuando fuese necesario. Había leyes que amenazaban la estabilidad de la nación, como el sufragio universal, el sistema económico, la ley militar. Todo esto hacía evidente — según Cánovasque la Monarquía necesitaba un cambio de gobierno ${ }^{194}$. Pero no se produjo entonces.

\subsubsection{La ley sobre el matrimonio civil}

El regreso de Cánovas no se veía próximo. La Regente mantuvo a Sagasta en el poder ${ }^{195}$. Se convocaron las Cortes para el 1 de diciembre. La oposición protestó por la tardanza. Lo consideraron una estrategia política, ya que de esta forma no se debatirían unos proyectos de ley y propuestas de cierta importancia. Entre éstas, la base tercera del Código Civil referente al matrimonio no se presentaría para su aprobación hasta enero ${ }^{196}$. Esto pondrá a prueba las buenas relaciones entre el Estado y la Santa Sede.

Las negociaciones con la Santa Sede sobre la base tercera habían comenzado en la legislatura anterior, siendo todavía nuncio el cardenal Rampolla ${ }^{197}$. El gobierno quería presentar una ley sobre matrimonio civil para los no católicos. Las negociaciones se centraron en el derecho del Estado a legislar sobre el matrimonio de los ciudadanos. La Iglesia quería, por su parte, defender su potestad sobre los católicos, para los que la única forma válida de matrimonio era el canónico, cualquier otra fórmula sería permitir el concubinato. Así se veía la ley presentada por el gobierno. Ésta exigía la presencia de un oficial del juzgado sólo para la inscripción, sin que eso fuera necesario para la validez del matrimonio entre católicos. Rampolla respondió negativamente a la propuesta del

19445 Di Pietro-Rampolla, 25 octubre 1887. ASV SS 249 (1887), 3, ff. 176-178.

19566 Di Pietro-Rampolla, 1 diciembre 1887. ASV SS 249 (1887), 3, f. 189.

19652 Di Pietro-Rampolla, 8 noviembre 1887. ASV SS 249 (1887), 3, ff. 187-188.

197 Sobre la negociación de la base tercera del Código Civil durante la nunciatura Rampolla y el resultado de la misma: Cfr. C. Robles MuÑoz, «La base sobre el matrimonio en el Código Civil. El Acuerdo con la Santa Sede (1887)», Revista Española de Derecho Canónico, 41 (1985), 365-380. 
gobierno. Alonso Martínez presionó. Era un proyecto de corte conservador, ningún gobierno admitiría rebajarlo ${ }^{198}$. Desde la Santa Sede querían tener la seguridad, por parte del gobierno, de que la presencia de un empleado del juzgado sólo se exigiría para la validez de la inscripción en el Registro, nunca para la del acto $^{199}$.

El embajador ante la Santa Sede recibió órdenes para que despejara cualquier duda sobre las intenciones del gobierno. Había que evitar que radicales y carlistas utilizasen la negativa del Papa para atacar el principio monárquico y la legalidad $^{200}$. Finalmente la Santa Sede accedió después de una larga negociación de Groizard con el Secretario de Estado ${ }^{201}$. El Papa aprobó las dos partes de la Base 3. ${ }^{a}$ del Código Civil sobre el matrimonio de los católicos. Dejaba al Estado el derecho a regular los efectos civiles del matrimonio, al mismo tiempo que no se ponía en cuestión la doctrina de la Iglesia sobre el matrimonio de los no católicos ${ }^{202}$.

La razón que Groizard había dado en las negociaciones, para que por fin la Santa Sede aprobara el proyecto, era que con la aceptación de la propuesta no se daría pie para que nadie, en nombre de la Santa Sede, pudiera atacar la política gubernamental, perturbando de esta forma la paz y la concordia obtenida:

«Aquella antigua tradición de hostilidad a la Iglesia, de lucha, de incompatibilidad entre la paz religiosa y el gobierno de los partidos liberales, y de medidas de violencia para llegar después a transacciones más o menos plausibles, ha desaparecido de la historia de España dando lugar a una política de respeto y de prudente iniciativa así como de profunda consideración hacia la Santa Sede; de tal suerte que los progresos requeridos por el tiempo e impuestos a los gobiernos por las necesidades de la época se lleven a feliz término con la aquiescencia del Sumo Pontífice, condición bienhechora que da a la religiosa España aquella tranquilidad y aquella calma en los espíritus que es condición indispensable para la felicidad de los pueblos» ${ }^{203}$.

198558 Rampolla-Jacobini. Minuta, 15 diciembre 1886. ASV NM 539, Tít. VI, Rub. II, Sez. única 1, ff. 230-231.

19969186 Jacobini-Rampolla, 17 enero 1886. ASV NM 539, Tít. VI, Rub. II, Sez. única 1, f. 229.

200 Moret-Groizard, 24 febrero 1887. AMAE Santa Sede H 2675.

201 Cifras y telegramas comunicando los pasos dados por Groizard en AMAE. Santa Sede H 2675.

202 «Sua Santitá approva quanto nelle due parti della Base si riferisce al matriminio fra Cattolici. La Santa Sede lascia allo Stato di regolare gli effetti civili del matrimonio. Colla precedente approvazione non s'intende punto pregiudicata la dottrina della Chiesa circa i matrimonii degli eterodossi; ed il Santo Padre potrá tollerare che il Governo prenda intorno ad essi le opportune misure»: Mocenni-Groizard, 8 marzo 1887. Anexo a 36 Groizard-Moret, 8 marzo 1887. AMAE. Santa Sede H 2675.

20337 Groizard-Moret, 8 marzo 1887. AMAE. Santa Sede H 2675. En una entrevista posterior, entre Groizard y León XIII, el embajador español agradeció al Papa la aprobación de la ley sobre el matrimonio. León XIII manifestó su disposición a favorecer al gobierno español «en cuanto lo consintiera el dogma de la Iglesia»: 86 Groizard-Moret, 26 abril 1887. AMAE H 1739.

Hispania Sacra, Legalidad y conflictos, 58

117, enero-junio 2006, 171-222, ISSN: 0018-215-X 
En el Senado preguntaron al ministro de Justicia por las negociaciones con el Vaticano. Alonso Martínez respondió que era el Estado quien tenía el derecho a legislar sobre las familias, pero había que tener en cuenta que la religión del Estado era la católica. Las conversaciones con la Santa Sede habían comenzado por el deseo de mantener el espíritu de concordia y de paz que había entre las potestades. Era la forma de establecer sobre bases sólidas la paz religiosa. Se llegó a un acuerdo que aprobó la Santa Sede, reconociendo al Estado el derecho para regular los efectos civiles del matrimonio ${ }^{204}$.

El acuerdo con la Santa Sede trajo, en palabras de Moret, «paz a las conciencias y satisfacción a graves necesidades de Gobierno». Era cierto que el ministerio Sagasta representaba una política radical. Ahora bien, también era cierto que la regencia y el gobierno habían contraido una deuda de agradecimiento hacia el Papa. Había terminado el tiempo de lucha entre la Iglesia y el Estado, la «incompatibilidad entre la paz religiosa y el Gobierno de los partidos liberales». Era el momento de la política del respeto, lo que permitiría dejar a un lado los tiempos de violencia e intransigencia ${ }^{205}$.

A finales de agosto Moret, en un discurso pronunciado en Sevilla, trató sobre las buenas relaciones entre el gobierno y la Iglesia ${ }^{206}$. Era el preámbulo para anunciar que aquel presentaría un proyecto de ley sobre el matrimonio civil. Éste sería aceptado por el Vaticano, lo que demostraría la armonía que existía entre el poder civil y el eclesiástico ${ }^{207}$.

En las semanas previas a la apertura de las Cortes, El Imparcial dio la noticia de una posible unión de España a la Triple Alianza, Alemania, Italia y Austria. Parecía más un deseo de estas potencias que una realidad. Las circunstancias de España, un ejército indisciplinado, una economía en crisis, no hacían viable esta unión. Tampoco desde la Santa Sede la veían con buenos ojos; era el tiempo en el que León XIII comenzaba a dirigir su mirada hacia Francia, después de que fracasara una posible alianza con los emperadores de Austria, Alemania y Rusia contra Italia. El apoyo que se le podría prestar al reino italiano, precisamente cuando el Papa luchaba por recuperar el poder temporal, hubiera sido perjudicial para las relaciones entre España y la Santa Sede. Cánovas, por su parte, veía necesario que España permaneciera neutral ${ }^{208}$.

204 DSS, 45 (14 marzo 1887), 986-987.

205 Moret-Groizard, 16 marzo 1887. AMAE Santa Sede H 2675.

20621 Di Pietro-Rampolla, 22 agosto 1887. ASV SS 249 (1887), 3, f. 9.

207 El Sr. Moret en Sevilla. «El Liberal» (20 agosto 1887), 1.

20854 Di Pietro-Rampolla, 12 noviembre 1887. SS 249 (1887), 3, ff. 151-152. Cfr. M. FERNÁNDEZ Rodríguez, «España y la Triple Alianza», Boletín de la Real Academia de la Historia, 185 (1988), 83-144; J. ANDRÉs-GALLEGO, Un 98 distinto. Restauración, desastre, regeneracionismo, pp. 107-112. 
Radicales y conservadores atacaban al gobierno. Unos exigían llevar hasta sus últimas consecuencias la política liberal; otros querían una legislación acorde a la España católica.

En el discurso que Martos, Presidente del Congreso, hizo con motivo de la onomástica del Rey propuso lo que debía ser un proyecto de política liberal. España debía situarse al nivel de las naciones cultas mediante instituciones libres. No era éste el pensamiento del partido fusionista, como indicaron al nuncio ${ }^{209}$. A pesar de que los fusionistas se desvincularon del discurso de Martos, necesitaban el apoyo de los demócratas para un programa común que incluía el sufragio universal y la ley sobre los jurados. Los partidos de la minoría y algunos miembros notables de la mayoría estaban haciendo una oposición durísima al gobierno. La crisis agrícola y económica, la reforma militar, la cuestión de Marruecos y la administración de las islas de Cuba y Puerto Rico eran los argumentos de la oposición.

Desde el partido conservador, Cangas-Argüelles había pedido que se excluyeran los delitos de lesa Majestad divina de los juicios por jurados. Alonso Martínez respondió señalando que un jurado integrado, en una gran mayoría, por católicos sería más duro que un juez de mentalidad liberal. Cánovas, por su parte, en un discurso a los miembros de su partido acusó, al gobierno de traer la revolución por su unión con los demócratas 210 .

Ahora bien, el motivo de mayor tensión en las relaciones entre la Iglesia y el Estado sería la presentación del proyecto de ley sobre el matrimonio civil. El gobierno no cumplió con lo pactado. Alonso Martínez presentó en el Congreso un proyecto con una modificación que aludía a la validez del matrimonio que los españoles podían contraer en el extranjero, según las leyes establecidas en el país, siempre que éste no estuviera en contra de los establecido en el código español, es decir, matrimonio indisoluble y a perpetuidad ${ }^{211}$. El párrafo quería ser un guiño a las posturas más radicales del partido liberal. El gobierno daba a entender que el proyecto presentado estaba negociado y acordado con la Santa Sede. Su última parte permitía que los católicos pudieran contraer matrimonio civil en el extranjero, rompiendo el pacto que había con el Vaticano ${ }^{212}$.

La Santa Sede no podía admitir esto. Se permitía de hecho a los católicos escoger libremente entre matrimonio civil o canónico ${ }^{213}$. Di Pietro se entrevistó con Moret para aclarar lo sucedido. El nuncio recibió las excusas presentadas por el ministro de Gracia y Justicia. Según Alonso Martínez había sido una pro-

\footnotetext{
20990 Di Pietro-Rampolla, 24 enero 1888. ASV SS 249 (1888), 1, ff. 85-86.

210 Particular. Di Pietro-Rampolla, 5 febrero 1888. ASV SS 249 (1888), 3, ff. 4-7.

211 DSC, 93 (2 diciembre 1887), Apéndice 4.

21299 Di Pietro-Rampolla, 14 febrero 1888. ASV SS 249 (1889), fascículo único, f. 8.

21374145 Rampolla-Di Pietro. Minuta, 15 febrero 1888. ASV SS 249 (1889), fascículo único, f. 19.
} 
puesta hecha por el partido conservador. En consecuencia, la postura de los liberales no podía ser más intransigente que la conservadora. El nuncio respondió negando el hecho. El partido conservador había presentado una enmienda como proyecto, sin tener en cuenta el acuerdo con la Santa Sede que no podía conocer $^{214}$.

La propuesta del ministro de Gracia y Justicia provocó la división en el seno del gobierno. Alonso Martínez se quedaba solo. Sagasta y los demócratas del partido estaban en contra del añadido. El nuncio estaba seguro que se retiraría el párrafo en discusión ${ }^{215}$.

Así lo confirmó el mismo Alonso Martínez en su respuesta al republicano Azcárate. Éste interpeló al ministro sobre las negociaciones con Roma y la interferencia de la Santa Sede en las competencias del Estado para legislar sobre el matrimonio civil ${ }^{216}$. El Estado - respondió Alonso Martínez- no tenía competencias para legislar sobre un sacramento; sí lo podía hacer sobre el matrimonio de los españoles pero sin entrar en un terreno que no era de su competencia. El gobierno se acomodaba al estado de las cosas; quería evitar que se rompiera el pacto de concordia entre la Iglesia y el Estado. Era la política seguida desde que llegaron al gobierno y los hechos demostraban que se había conseguido la paz y la tranquilidad. Incluso había servido para quitar influencia al partido carlista, cuya fuerza principal estaba en el clero, mientras éste pensase que en el partido liberal tenía un enemigo contra los derechos de la Iglesia. Por eso desde el comienzo, el gobierno liberal se había propuesto demostrar que «las instituciones actuales, son perfectamente compatibles con la existencia de la armonía y de la concordia entre la Iglesia y el Estado; que nada tenía que temer la Iglesia de nosotros, que nada tenía que temer de la Regencia ni del partido liberal» ${ }^{217}$.

Al final del debate con Azcárate, Alonso Martínez explicó la fórmula que presentaba para su aprobación. En ella omitía la parte controvertida. Esto permitió al nuncio escribir a Roma asegurando que el gobierno aceptaba las exigencias de la Santa Sede ${ }^{218}$. En el debate del Senado sobre la base tercera del Código Civil, que recogía el proyecto sobre el matrimonio, el obispo de Salamanca abundó sobre las mismas ideas. Se había logrado un proyecto común, obra de hombres de todas las procedencias, pero con amor sincero a la Iglesia y a la Patria. Si se hubiesen abierto viejas heridas la Iglesia no podría acudir en ayuda del Estado cuando a éste le hiciera falta:

214101 Di Pietro-Rampolla, 17 febrero 1888. ASV SS 249 (1889), fascículo único, f. 21.

215108 Di Pietro-Rampolla, 7 marzo 1888. ASV SS 249 (1889), fascículo único, f. 26.

216 DSC, 68 (10 marzo 1888), 1741-1743.

217 DSC, 68 (10 marzo 1888), 1743-1748.

218110 Di Pietro-Rampolla, 11 marzo 1888. ASV SS 249 (1889), fascículo único, f. 29. 
«Esa es la gran base de la concordia [...] La tranquilidad en el orden, lo primero el orden de la verdad, después el orden que fluye y mana de esa misma verdad en la práctica de la vida, y entonces llegue el dulce abrazo entre el Estado y la Iglesia, y estaremos todos perfectamente hermanados para el común proyecto y bienestar» ${ }^{219}$.

\section{LAS IDEAS DEFENDIDAS POR LACORDAIRE Y MONTALAMBERT}

El apoyo a la legalidad y a los poderes constituidos fue una opción de León XIII desde el comienzo de su pontificado. No era muy distinta la visión que el Papa tenía de la sociedad moderna respecto a la de su antecesor. Fue, en cambio, muy distinta la forma en la que el León XIII afrontó la posición de la Iglesia en general y de los católicos en particular ante la sociedad liberal ${ }^{220}$.

La elección del cardenal Pecci como sucesor de Pío IX coincidió con una concentración de radicales y socialistas contra la ley de garantías ${ }^{221}$; y una pretendida concentración para pedir la expulsión del Papa de Roma, que Crispi prohibió, pero obligó a acelerar las votaciones del cónclave ${ }^{222}$.

Tras la designación hubo un hecho significativo. El anuncio se hizo hacia el exterior de la basílica de San Pedro, aunque la bendición posterior la dio el

219 DSS, 51 (21 febrero 1889), 828-843.

El diputado Danvila solicitó al ministro Alonso la documentación sobre la negociación con la Santa Sede. El ministro solicitó el expediente al Ministerio de Estado. Aquí anotaron: «El expediente de las últimas negociaciones sobre el matrimonio civil es de un carácter tan reservado y de naturaleza tan delicada que no parece conveniente se facilite a las Cámaras»: Nota, s.f. AMAE. Santa Sede H 2675.

La respuesta al ministro fue evasiva: «... tengo la honra de poner en su conocimiento que no existiendo en este Ministerio el expediente original sobre las negociaciones entabladas con la Santa Sede respecto a la forma en que debía celebrarse en España el matrimonio canónico y el civil, y solo un legajo con algunos telegramas de carácter reservado y confidencial no es posible, con el mejor deseo, disponer la remisión solicitada»: Minuta. Vega de Armijo-Alonso Martínez, 31 enero 1889. AMAE. Santa Sede H 2675.

${ }^{220}$ Quiso dar una imagen distinta de la Iglesia. Recuperar el papel que ésta había tenido a lo largo de la historia como defensora de los valores fundamentales de cada época, manteniendo la concordia entre las naciones: «Al mismo tiempo dirigimos nuestra palabra a los reyes y a los jefes de Estado de todos los pueblos y les rogamos con reiterada insistencia, en el nombre del Dios Altísimo, que no rechacen el apoyo que en estos peligrosos tiempos les ofrece la Iglesia; que se agrupen en amigable concordia en torno a esta fuente de autoridad salvadora y que se unan a ella cada vez más con los lazos del respeto y de un íntimo cariño»: LEón XIII, Inscrutabili Dei, n. 11. J. L. GutIÉRREZ GarCía (ed.), Doctrina Pontificia, vol. II, Documentos políticos, p. 52.

${ }^{221}$ En mayo de 1871 fue aprobada la ley de garantías por la que se consideraba al Papa un súbdito italiano, aunque sujeto de determinados derechos en cuanto Pontífice, como por ejemplo recibir honores de soberano; una pensión anual; el derecho de representación. Sin embargo sometía la libertad de la Iglesia a las decisiones del Parlamento italiano. Cfr. G. Martina, Storia della Chiesa da Lutero ai nostri giorni. Vol. III: L'età liberale, Brescia, 1998, p. 240.

${ }^{222}$ Sobre los preparativos del cónclave de 1878 , los grupos y tendencias de los cardenales, y la tensión que en esos días se vivía en Roma, con las manifestaciones de los radicales: Cfr. D. I. KERTZER, Prigionero del Vaticano. Pio IX e lo scontro tra la Chiesa e lo Stato Italiano, Milano, 2005, pp. 147-168.

Hispania Sacra, Legalidad y conflictos, 58

117, enero-junio 2006, 171-222, ISSN: 0018-215-X 
Papa en el interior de la iglesia. Era el primer acto de estas características que se celebraba en Roma desde 1870. En una audiencia posterior, concedida al embajador español, el Papa manifestó su confianza en el gobierno italiano, a pesar de los incidentes provocados por los partidos extremos ${ }^{223}$.

El primer acto del Papa, la bendición dentro de la basílica «a puerta abierta», indicaba que León XIII quería estar cerca de los católicos. Fue un hecho que, sin embargo, provocó el malestar de los partidarios del poder temporal del Papa, ya que «no pueden tolerar que los que no han militado con ellos en las luchas políticas, vean y oigan con ellos al Santo Padre». Intentarían que el nuevo Papa mantuviese la misma conducta que Pío IX tras los sucesos de Porta Pía. Con este objetivo pretendían influir para que el Papa mantuviese en el puesto de Secretario de Estado al cardenal Simeoni y que la coronación se celebrase a puerta cerrada.

Las esperanzas de los «romanos» fallaron en parte. Hicieron correr el rumor de que el Papa mantendría en su puesto al anterior Secretario de Estado de Pío IX. La noticia llegó a tener tintes de verosimilitud y así lo comunicaron los embajadores a las respectivas cancillerías. Sin embargo, León XIII nombró al cardenal Franchi como Secretario de Estado y a Simeoni, prefecto de Propaganda Fidei $^{224}$.

En cuanto a la coronación del Papa, los rumores propagados por los «romanos», consiguieron el efecto oportuno. Avisaron a León XIII que los «italianos», partidarios de la reconciliación con Italia, interrumpirían la celebración entrando en la basílica con una bandera blanca y gritando «Viva el Papa y la conciliación». Estos, en cambio, acusaron a los «romanos» de querer proclamar al «Papa-Rey». Finalmente, León XIII decidió celebrar el acto de coronación en la Capilla Sixtina, cuando un «distinguido diplomático» informó al Papa que los liberales pretendían obligarle a aceptar la reconciliación con Italia. El resultado fue que la opinión pública consideró el acto como «síntoma de las tendencias más intrasigentes en el Vaticano» ${ }^{225}$.

Sin embargo, el nombramiento del Secretario de Estado puso de manifiesto una política distinta a la de Pío IX. Ahora bien, según el embajador español, había algunas cuestiones que inquietaban al mundo católico:

«... ¿cuáles podrán ser las manifestaciones de esta tendencia nueva en el terreno de los hechos? ¿En qué puntos podrá diferenciarse la nueva de la antigua política? ¿Dentro de qué límites de espacio y tiempo llegará a manifestarse y desenvolverse?».

22315 Cárdenas-Silvela, 21 febrero 1878. AMAE Protocolo H 3410.

224 En julio de ese mismo año murió el Secretario de Estado. Fue sustituido por el cardenal Nina, hasta el momento Prefecto de la Congregación de Estudios: «El Secretario de Estado de Su Santidad el Papa León XIII», Boletín Eclesiástico del Arzobispado de Toledo, 26 (1878), 299-300.

22526 Cárdenas-Silvela, 4 marzo 1878. AMAE Protocolo H 3410. 
Unos, manifestando más un deseo que una realidad, estaban convencidos que León XIII mantendría la misma postura tirante frente a los Estado liberales y no celebraría actos solemnes en San Pedro. Otros estaban convencidos que el Papa rompería «la clausura del Vaticano»; restablecería el esplendor de San Pedro, a pesar de las penalidades, y «manten[dría] buenas relaciones, aunque privadas, con el Rey de Italia, y venir por este medio, sino a una conciliación, a un modus vivendi con el Gobierno italiano».

Había, sin embargo, dos grupos que querían expulsar el Vaticano de Roma. Por una parte los radicales; por otra, los zelantes, «con el deseo de mandar a la Santa Sede a un largo peregrinaje como solución a las calamidades». León XIII, por su parte, pensaba realizar una política que mantuviese los principios y cambiase en las formas; evitando aquellas cuestiones que, sin ser fundamentales, podrían afectar en la relación con los Estados. Había hechos que ponían esto de manifiesto. León XIII había dado los primeros pasos para restablecer las relaciones con Alemania y Rusia ${ }^{226}$.

Los hechos posteriores demostrarían que la elección de León XIII y el cambio de rumbo en la política vaticana fue un paso importante en la reconciliación de la Iglesia con los Estados liberales. Significó el triunfo de «aquellas generosas ideas defendidas hace cincuenta años por Lacordaire y Montalambert, que en medio del aplauso universal proclamaron la absoluta conpatibilidad de la Iglesia Católica con el progreso y con la libertar moderna en todas sus aplicaciones».

El enfrentamiento entre la Iglesia y los Estados liberales había provocado el recelo y la desconfianza; había impedido la unión de esfuerzos debido a los excesos del liberalismo y el debilitamiento del principio religioso.

Esta nueva orientación se puso de manifiesto, en España, tras la muerte de Alfonso XII. La pastoral de los obispos y el mensaje de León XIII a la Regente, eran prueba de ello. La primera consecuencia de esto fue la marginación del partido carlista. Ahora los carlistas ya no podían apropiarse el título de católico y estaban «en la alternativa de someterse y sucumbir, o de rebelarse contra la Iglesia». En opinión de Moret, el partido carlista no tendría más opción, si no quería acabar en el suicidio político, que incorporarse a la legalidad y presentarse como un partido conservador más.

Sin embargo, también era cierto que un sector del carlismo no estaba dispuesto a someterse a las indicaciones del Papa ni de los obispos. Los más extremistas estaban convencidos que sólo provocando la caída de la legalidad vigente podrían subsistir. Con este fin estaban dispuestos a favorecer una revolución antimonárquica, de esta forma, «encontrándose frente a frente la República so-

22628 Cárdenas-Silvela, 17 marzo 1878. AMAE Protocolo H 3410.

Hispania Sacra, Legalidad y conflictos, 58

117, enero-junio 2006, 171-222, ISSN: 0018-215-X 
cialista y anárquica con el Carlismo», recibirían el apoyo de la Iglesia como defensores del orden.

La segunda consecuencia de la política de León XIII era la leal colaboración entre la Iglesia y el Estado, «armonizando la acción pública del Estado con la del Clero para todas aquellas reformas sociales en que tanta influencia puede ejercer dentro del país». Ahora bien, el mayor problema que había para esta alianza era la escasa formación del clero. De ahí que fuese necesario aprovechar a aquellos clérigos, que por su cultura pudieran dedicarse a la formación de los seminaristas. Esta sería la forma de influir en las «diferentes esferas de acción de la civilización moderna en que la moral vale más que la acción civil y en que la acción civil secundada por la moral lo puede todo» ${ }^{227}$.

En la mente de León XIII estaba, según el embajador español, conseguir la paz religiosa entre la Iglesia y los Estados ${ }^{228}$. El Papa estaba dispuesto a negociar con la sociedad, ofreciendo aquello que la Iglesia tenía, «su prestigio para que mejor puedan defenderse de los ataques de la anarquia, los principios fundamentales en que descansan todos los organismos sociales». Con este fin había que eliminar recelos y crecer en confianza mutua, especialmente en la enseñanza, donde más necesario era fortalecer la autoridad pública mediante la acción moral y el sentimiento religioso de los ciudadanos ${ }^{229}$.

En vísperas de su marcha a Roma, Rampolla quiso despedirse de su amigo Moret. El cardenal puso de manifiesto las simpatías y el favor del Papa a a la regencia. León XIII estaba dispuesto a favorecer a la Monarquía y poner de su parte para evitar cualquier tipo de revolución. Sabía que las ideas modernas no eran ni las mejores, ni serían definitivas. Pero toleraba y daría «al Cesar cuanto es del Cesar y al pueblo cuanto es del pueblo, con la sola condición de levantar

227 Moret-Groizard, 2 abril 1886. AMAE H 1739.

228 A esto convocaría a los católicos franceses, invitándoles a incorporarse a las instituciones de la III República: «... cuando de hecho quedan constituidos nuevos regímenes políticos, representantes de este poder inmutable, su aceptación no solamente es lícita, sino incluso obligatoria, con obligación impuesta por la necesidad del bien común, que les da vida y los mantiene. Aceptación obligatoria cuya urgencia es mayor cuando las revoluciones acentúan el odio común, provocan la guerra civil y pueden sumir a la nación en el caos de la anarquía. Esta grave obligación de sumisión y obediencia durará todo el tiempo que requieran las exigencias del bien común. Porque después de Dios, el bien común es la primera y última ley de la sociedad humana». LEÓN XIII, Au milieu des sollicitudes, n. 23. J. L. GuTIÉRREZ García (ed.), Doctrina Pontificia, vol. II. Documentos políticos, p. 306. Sobre las divisiones de los católicos franceses y la encíclica del Papa: Cfr. C. RoBles MuÑOz, «En el corazón de la democracia. León XIII y Francia», Anthologica Annua, 39 (1992), 274-285.

229 «Un antagonismo doctrinal entre el Estado y la Iglesia es absurdo y solo puede redundar en beneficio de los partidos extremos. Si logramos reemplazar con una confianza mutua los recelos en todas las esferas, pero muy particularmente en la esfera de la enseñanza, el poder público verá fortalecida la autoridad de sus leyes con aquella fuerza virtual que les presta su paraleleismo con la acción de la moral y con la dirección del sentimiento religioso de los pueblos»: 88 Groizard-Moret, 10 mayo 1886. AMAE Santa Sede H 1739. 
el espíritu religioso y de elevar el concepto y la autoridad del Pontificado en la mente de todos los pueblos civilizados».

Después de hablar sobre la necesaria formación del clero y la creación de un Seminario nacional en Madrid, con la ayuda del marqués de Urquijo, la conversación terminó con una petición de Moret a León XIII:

«... que el Santo Padre continúe la misma línea de conducta que hasta ahora había tenido con España [...] alta política de tolerancia, de conciliación y de elevación de miras que caracteriza la vida del actual Pontífice y dará al final del siglo XIX especial tinte y simpática significación» ${ }^{230}$.

${ }^{230}$ Minuta. Moret-Groizard, 4 mayo 1887. AMAE Santa Sede H 2675.

Hispania Sacra, Legalidad y conflictos, 58

117, enero-junio 2006, 171-222, ISSN: 0018-215-X 